2016 - Volume: 17 Number: 2

Page: $357-376$

DOI : $10.18038 / \mathrm{btda} .05228$

Received: 09 April 2016 Accepted: 06 June 2016

\title{
SYNTHESIS, CHARACTERIZATION, CRYSTAL STRUCTURE AND THEORETICAL STUDIES OF N-(2,4-DICHLOROBENZYLIDENE)-3-METHYLBENZENAMINE
}

\author{
Türkay AYTEKIIN ${ }^{1, ~}$, Dilek ELMALI ${ }^{2}$, Halil BERBER ${ }^{2}$, Filiz ŞIŞMAN² \\ ${ }^{1}$ Department of Physics, Science Faculty, Anadolu University, 26470 Eskişehir, Turkey \\ ${ }^{2}$ Department of Chemistry, Science Faculty, Anadolu University, 26470 Eskişehir, Turkey
}

\begin{abstract}
N-(2,4-dichlorobenzylidene)-3-methylbenzenamine (L6) was synthesized as single crystal and characterized by FT-IR, Raman, ${ }^{1} \mathrm{H}$ NMR, ${ }^{13} \mathrm{C}$ NMR and UV-VIS spectroscopy. The thermal stability of the title compound was also studied by thermogravimetric analysis (TGA) and differential thermal analysis (DTA) analyses. The optimized geometric parameters, conformational analysis, normal mode frequencies and corresponding vibrational assignments of L6 was theoretically examined by means of density functional theory (DFT) method using the Becke-3-Lee-Yang-Parr (B3LYP) exchangecorrelation functional and the $6-311 \mathrm{G}++(\mathrm{d}, \mathrm{p})$ basis sets. The DFT based nuclear magnetic resonance (NMR) calculations were also performed to be used for assigning the ${ }^{1} \mathrm{H}$ and ${ }^{13} \mathrm{C}$ NMR chemical shifts of $\mathbf{L 6}$. Reliable vibrational assignments were investigated by the potential energy distribution analysis and the highest occupied and the lowest unoccupied molecular orbitals (HOMO and LUMO) of L6 was predicted. A good consistency were obtained between the theoretically predicted structural parameters, vibrational frequencies and those obtained experimentally.
\end{abstract}

Keywords: Nitrile, Metallophthalocyanine, Cyclotetramerization, Macrocyclic

\section{INTRODUCTION}

Hugo Schiff described the condensation between an aldehyde and an amine leading to a Schiff base in the 1860s [1]. Since then a variety of methods for the synthesis of Schiff bases have been described. Schiff base ligands may contain a variety of substituents with different electron-donating or electronwithdrawing groups and therefore may be interesting chemical properties [1]. A Schiff base is the nitrogen analogue of aldehyde in which the $\mathrm{C}=\mathrm{O}$ group is replaced by a $\mathrm{C}=\mathrm{N}$ group [2]. Schiff bases, also known as $\mathrm{N}$-substituted imines have been widely studied as ligands in the development of organic coordination complexes of transition metals [1-3]. Schiff bases constitute one of the most widely used families of organic compounds, not only as synthetic intermediates but also in coordination chemistry [2]. Under ordinary conditions aromatic aldehydes and aromatic amines react very readily to give Schiff bases. These Schiff bases are well-defined, crystalline substances. Many studies show the biological role of Schiff bases as anticancer, antitumor, non-steroidal anti-inflammatory drugs [4-9]. The imines derived from aniline and its derivatives with aromatic aldehydes have a wide variety of applications, particularly in biological, pharmaceutical and other chemical industries [9-12]. We reported the synthesis, crystal structure, characterization and theoretical studies of Schiff base compound L6. The literature survey reveals that to the best of our knowledge no detailed study available on FT-IR, Raman, ${ }^{1} \mathrm{H}$ NMR, ${ }^{13} \mathrm{C}$ NMR and UV-VIS spectroscopy, single crystal and the thermogravimetric (TGA/DTA) study on $\mathbf{L 6}$.

\footnotetext{
*Corresponding Author: maytekin@anadolu.edu.tr
} 
Aytekin et al. / Anadolu Univ. J. of Sci. and Technology - A - Appl. Sci. and Eng. 17 (2) - 2016

\section{EXPERIMENTAL SECTION}

\subsection{General}

All reagents and solvents for synthesis and spectroscopic studies were purchased from Aldrich and used without any further purification. The FT-IR $\left(4000-400 \mathrm{~cm}^{-1}\right)$ spectrum as a $\mathrm{KBr}$ pellet was recorded via a Bruker Optics IFS 66v/s FT-IR spectrometer with $2 \mathrm{~cm}^{-1}$ resolution in vacuum. For the Raman spectra, the compound was recorded using a Bruker Senterra Dispersive Raman microscope spectrometer at $532 \mathrm{~nm}$ excitation from a 3B diode laser having 9-18 $\mathrm{cm}^{-1}$ resolution between 3700 and $60 \mathrm{~cm}^{-1}$ spectral region. The ${ }^{1} \mathrm{H}\left(400 \mathrm{MHz} ; \mathrm{CDCl}_{3}\right)$ and ${ }^{13} \mathrm{C}\left(100 \mathrm{MHz} ; \mathrm{CDCl}_{3}\right) \mathrm{NMR}$ spectra were recorded on a Bruker Ultra Shield Plus-400 MHz instrument. Crystallographic data were collected on a Bruker AXS APEX [42] CCD diffractometer equipped with a rotation anode at 100 (2) K using graphite monochrometed Mo K $\alpha$ radiation $(\lambda=0.71073 \AA)$. Absorption corrections by psi-scan were applied. The data reduction was performed with the SAINT program package. Structure was solved by direct-methods and by full-matrix least squares against $\mathrm{F}^{2}$ using all data [43]. All non-hydrogen atoms were refined anisotropically. Hydrogen atoms were added to the structure model at calculated positions. Geometric calculations were performed with Platon [44]. Molecular drawings were obtained using Mercury [45]. Detailed crystallographic data for the structural analyses have been deposited with the Cambridge Crystallographic Data Centre, CCDC with deposition number 848120. Copies of this information can be obtained from The Cambridge Crystallographic Data Centre, 12 Union Road Cambridge CB21EZ, UK (fax: +44 1223 336033; e-mail: deposit@ccdc.cam.ac.uk or www: http://www.ccdc.cam.ac.uk. The thermogravimetric analyses were carried out at a heating rate of $20 \mathrm{C} / \mathrm{min}$ under nitrogen atmosphere using alumina powder as reference over a temperature range of 0-1400 C using a Netzsch STA 409 PC/PG thermal analyzer.

\subsection{Synthesis of $\mathbf{N}$-(2,4-dichlorobenzylidene)-3-methylbenzenamine}

2,4-dichlorobenzaldehyde $(175.01 \mathrm{mg}, 1 \mathrm{mmol})$ was dissolved in absolute ethanol $(50 \mathrm{ml})$ and the temperature was raised to $60^{\circ} \mathrm{C}$ and stirring was continued at this temperature until the aldehyde dissolved. Then 3-methylaniline $(107.17 \mathrm{mg}, 1 \mathrm{mmol})$ was added to the mixture. The whole mixture was stirred around an hour at room temperature to give a clear orange solution. Suitable crystals of the title compound for X-ray study were formed by slow evaporation of the solvent over two days at room temperature.

\section{RESULTS AND DISCUSSIONS}

The preparation of $\mathrm{H}_{2} \mathrm{Pc} 2$ and $\mathrm{CoPc} 3, \mathrm{CuPc}$ 4, NiPc 5 and $\mathrm{ZnPc} 6$ are shown in Figure 1. The structures of new compounds were characterized by using spectroscopic data and elemental analysis.

\subsection{Structural Property of L6}

The title compound L6 was obtained by the reaction of 2,4-dichlorobenzaldehyde with 3methylaniline in $84 \%$ yield in ethanol solution. L6 is a bottle straw yellow crystallite stable in air at room temperature. It is stable in air in the solid state. The crystal data and experimental details are listed in Table 1. The title compound crystallizes in the monoclinic system with space group of P2 (1) / c. The molecular structure of $\mathbf{L 6}$ with the atom numbering scheme and packing diagram of $\mathbf{L 6}$ with inter molecular interaction along b axis are given Figure 1 (a) and (b). SEM micrograph of L6 was investigated using a ZEISS EVO-50VP scanning electron microscope (SEM). The SEM micrograph of L6 is shown in Figure 1 (c). 
Aytekin et al. / Anadolu Univ. J. of Sci. and Technology - A - Appl. Sci. and Eng. 17 (2) - 2016

Table 1. Crystal data and structure refinement for $\mathbf{L 6}$

\begin{tabular}{|c|c|}
\hline Emprical formula & $\mathrm{C}_{14} \mathrm{H}_{11} \mathrm{Cl}_{2} \mathrm{~N}$ \\
\hline Formula weight & 264.14 \\
\hline Crystal system & Monoclinic \\
\hline Space group & $\mathrm{P} 2(1) / \mathrm{c}$ \\
\hline $\mathrm{T}(\mathrm{K})$ & $99(2)$ \\
\hline $\mathrm{a}(\AA)$ & $12.9046(2)$ \\
\hline $\mathrm{b}(\AA)$ & $3.86700(10)$ \\
\hline $\mathrm{c}(\AA)$ & $23.8971(4)$ \\
\hline$\alpha(\mathrm{deg})$ & 90 \\
\hline$\beta(\operatorname{deg})$ & $91.9500(10)$ \\
\hline$\gamma(\mathrm{deg})$ & 90 \\
\hline$V\left(\AA^{3}\right)$ & $1191.82(4)$ \\
\hline $\mathrm{Z}$ & 4 \\
\hline $\mathrm{D}_{\mathrm{x}}\left(\mathrm{Mgm}^{-3}\right)$ & 1.472 \\
\hline$\mu\left(\mathrm{mm}^{-1}\right)$ & 0.518 \\
\hline Crystal size (mm) & $0.56 \times 0.30 \times 0.28$ \\
\hline$T_{\min }$ & 0.7602 \\
\hline $\mathrm{T}_{\max }$ & 0.8685 \\
\hline Measured reflection & 11683 \\
\hline Independent reflection & 2990 \\
\hline Reflection with $\mathrm{I}>2 \sigma(\mathrm{I})$ & 0.0176 \\
\hline $\mathrm{CCDC}$ & 848120 \\
\hline
\end{tabular}

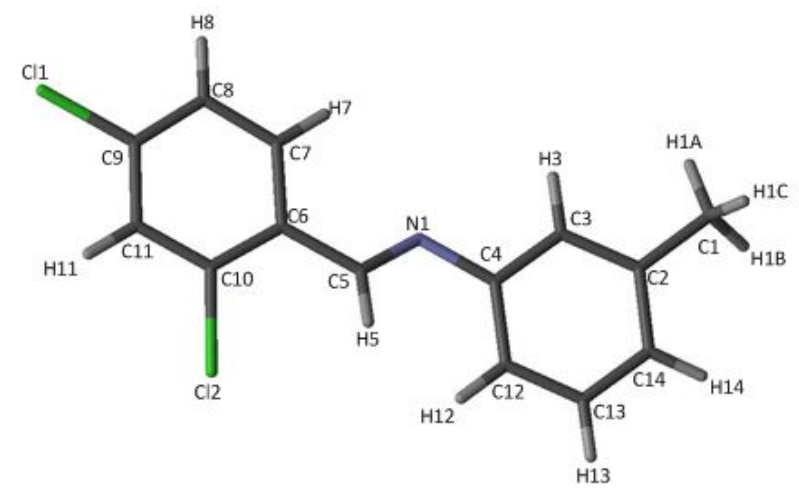

(a)

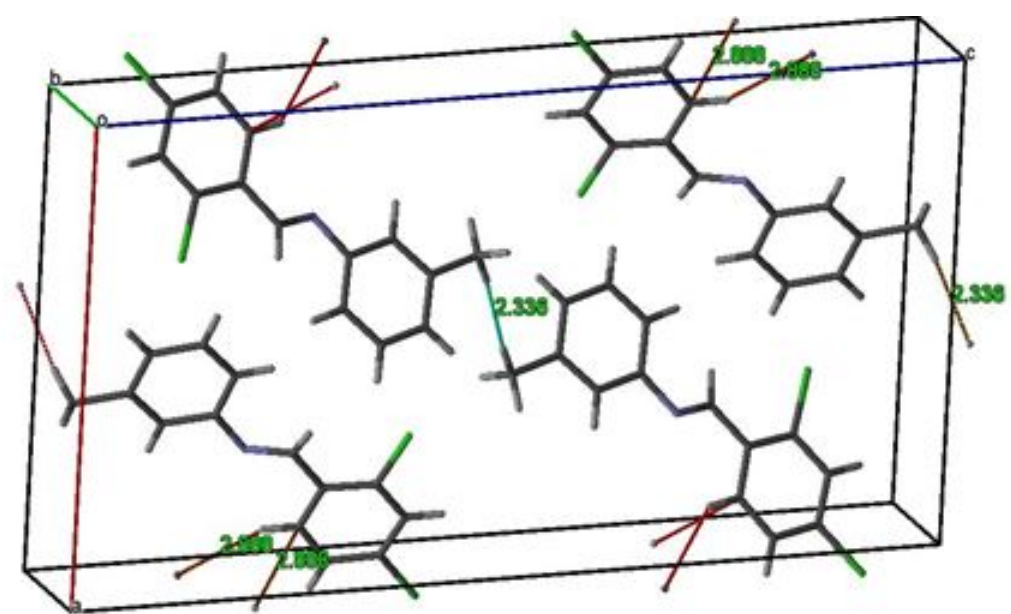

(b) 


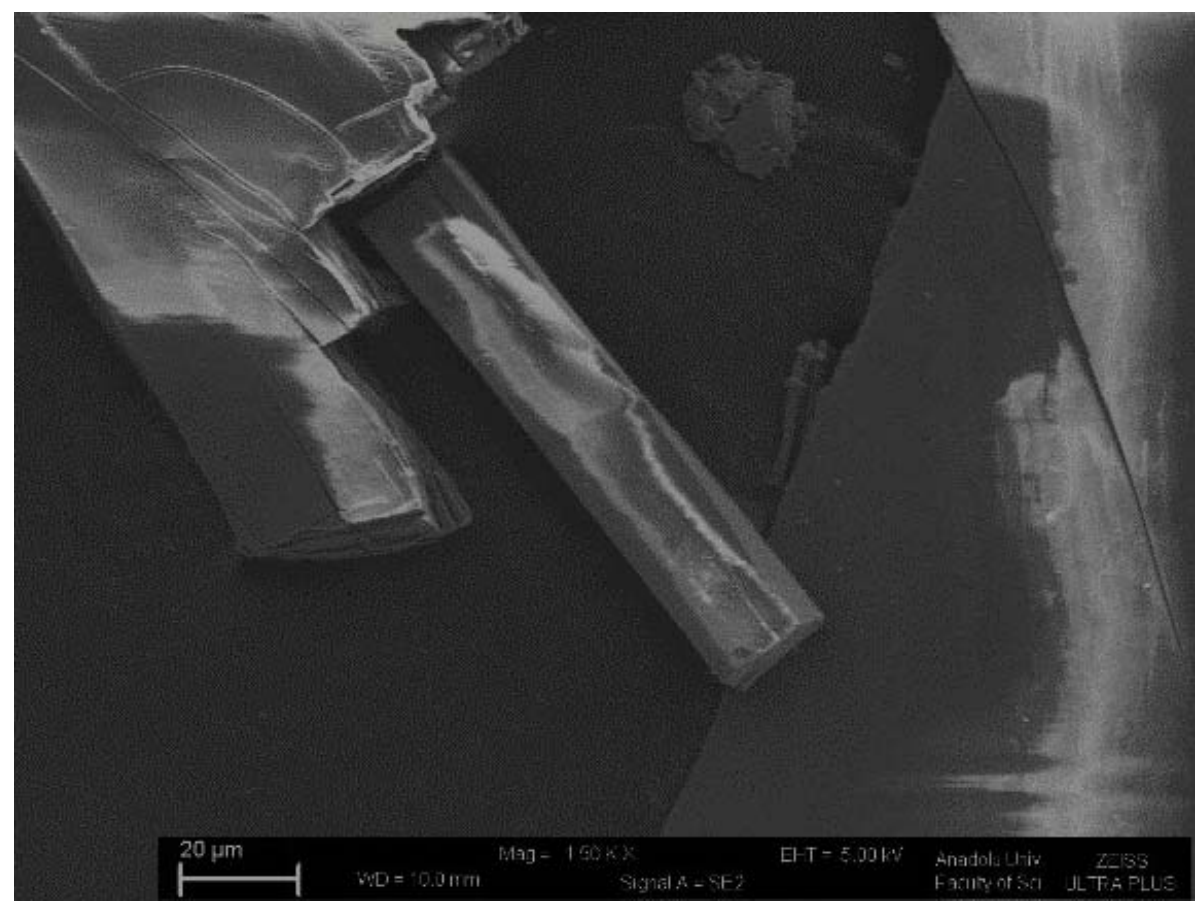

( c )

Figure 1. (a) The molecular structure of L6, (b) Packing diagram of L6 with inter molecular interaction along b axis, (c) SEM image of L6

\subsection{Computational Details}

All the theoretical calculations of the title compound were carried out with the aid of the CS ChemOffice Ultra 14.0.0.117 Version for Microsoft Windows [13], Gaussian 09 program [14] and GaussView 5.0.8 [15] was used for the molecular structure optimization and computation of vibrational wavenumbers. The optimized structural parameters of the title compound were used for harmonic vibrational frequency calculations at DFT level to characterize all stationary points as minima resulting in IR intensities and Raman depolarization ratios. In order to get the more stable conformers of the title compound the potential energy surfaces (PES) as a function of the selected torsion angle were obtained. Therefore, PES were determined by using Becke's three-parameter exchange functional [16] in combination with the Lee-Yang-Parr correlation functional [17] (B3LYP) density functional theory (DFT) method with split-valance polarized $6-311++G(d, p)$ basis set as implemented in Gaussian 09 program package. Different possible conformers could be proposed for L6 compound. All conformers initially were examined 6-31G(d) basis set and stability of the each conformers were also tested with $6-311++\mathrm{G}(\mathrm{d}, \mathrm{p})$ basis set at same theory level by using the Gaussian09 program package on a personal computer $[14,15]$. As a result of computations, four conformers were obtained. Conformational energies of the title compound were calculated as a onedimensional scan by varying the N1-C5-C6-C7 torsion angle from $0^{\circ}$ to $360^{\circ}$ in steps of $10^{\circ}$. The resulting plot of the potential energy surface (PES) scan for $\mathbf{L 6}$ is shown in Figure 2.

The more favorable conformers of the title compound were selected. For the selected conformers, we started by optimizing the molecular structures in the gas phase using density functional approach. The minimum energy conformer was further optimized at B3LYP/6-311++G(d,p) basis set. The vibrational frequency calculations were performed at the same level. The fundamental normal modes were assigned. The potential energy distribution (PED) calculations were carried out by the VEDA 4 (Vibrational Energy Distribution Analysis) program on a personal computer [18]. The calculated 
frequencies were scaled by 0.958 for greater than $1700 \mathrm{~cm}^{-1}, 0.983$ up to $1700 \mathrm{~cm}^{-1}$ [19]. The computed frequencies were scaled factors in order to improve the agreement with the experimental results. Although accurate vibrational frequencies are more difficult to compute, it is well known that DFT calculations give excellent agreement between molecular structure parameters and experimental vibrational frequencies are scaled to compensate the approximate treatment of electron correlation, basis set deficiencies and anharmonicity $[20,21]$. The scaling factors were not applied to the IR and Raman intensities. The ${ }^{13} \mathrm{C}$ NMR chemical shifts of the title compound were calculated using the keyword NMR in the DFT calculation at the B3LYP level with 6-311++G(d,p) basis set.

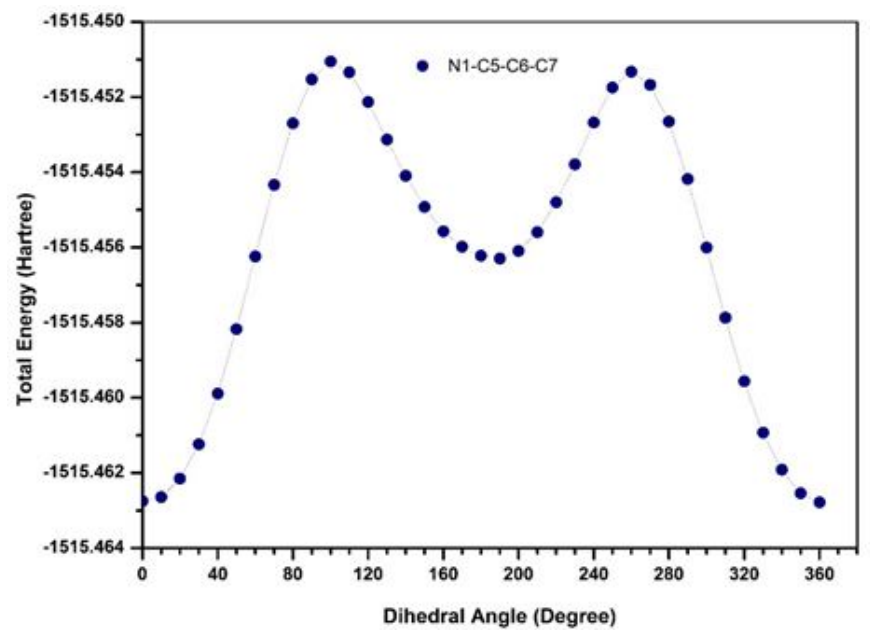

Figure 2. PES scan for the selected degree, $\mathrm{T}(\mathrm{N}-\mathrm{C}-\mathrm{C}-\mathrm{C})$ torsional freedom

The more favorable conformers of the title compound were selected. For the selected conformers, we started by optimizing the molecular structures in the gas phase using density functional approach. The minimum energy conformer was further optimized at B3LYP/6-311++G(d,p) basis set. The vibrational frequency calculations were performed at the same level. The fundamental normal modes were assigned. The potential energy distribution (PED) calculations were carried out by the VEDA 4 (Vibrational Energy Distribution Analysis) program on a personal computer [18]. The calculated frequencies were scaled by 0.958 for greater than $1700 \mathrm{~cm}^{-1}, 0.983$ up to $1700 \mathrm{~cm}^{-1}$ [19]. The computed frequencies were scaled factors in order to improve the agreement with the experimental results. Although accurate vibrational frequencies are more difficult to compute, it is well known that DFT calculations give excellent agreement between molecular structure parameters and experimental vibrational frequencies are scaled to compensate the approximate treatment of electron correlation, basis set deficiencies and anharmonicity $[20,21]$. The scaling factors were not applied to the IR and Raman intensities. The ${ }^{13} \mathrm{C}$ NMR chemical shifts of the title compound were calculated using the keyword NMR in the DFT calculation at the B3LYP level with 6-311++G(d,p) basis set.

\subsection{Molecular Geometry}

In the gas phase the selected molecular properties of the possible conformers of the compound L6 within calculated B3LYP theory level with 6-311 G ++ $(\mathrm{d}, \mathrm{p})$ basis sets are given Table 2 . The Table 2 point out that the $\mathrm{C} 2$ is a more stable conformer at room temperature $(298 \mathrm{~K})$ among the others taking into account the energies along with the population factors values. It is also worth noticing that the various basis sizes effect on $\triangle \mathrm{SCF}$ (self-consistent field energy) and $\Delta \mathrm{G}$ (the change in free energy) energies are not great and that the stability order for the conformers remains the same with the basis sets. The conformers are also in agreement with the single crystal structure data. In consistence with results obtained in the solid state, theoretical calculations predict that in the gas phase conformer $\mathrm{C} 2$ is the most stable ones. In addition, based on the theoretical results a planar structure for the conformers was found. 
Table 2. The selected molecular properties of the possible conformers of $\mathbf{L 6}$ molecule within calculated B3LYP theory level with 6-311++G(d,p) basis set

\begin{tabular}{|c|c|c|c|c|}
\hline \multirow{2}{*}{$\begin{array}{l}\text { Molecular Properties } \\
\text { (B3LYP/6311++G(d.p)) }\end{array}$} & \multicolumn{4}{|c|}{ Possible conformers } \\
\hline & L61 & L62 & L63 & L64 \\
\hline Symmetry & $\mathrm{C}_{1}$ & $\mathbf{C}_{1}$ & $\mathbf{C}_{1}$ & $\mathrm{C}_{1}$ \\
\hline$\mu_{\text {total }}($ debye $)$ & 1.29150 & 1.29270 & 2.41600 & 2.78380 \\
\hline $\mathrm{E}_{\text {total }}(\mathrm{kcal} / \mathrm{mol})$ & -950967.96560 & -950968.01960 & -950963.98410 & -950963.856010 \\
\hline$\Delta \mathrm{E}_{0}(\mathrm{kcal} / \mathrm{mol})$ & 0.05400 & 0 & 4.03550 & 4.16350 \\
\hline$\Delta \mathrm{G}(\mathrm{kcal} / \mathrm{mol})$ & -950863.8410 & -950864.72080 & -950860.74300 & -950860.67900 \\
\hline$\delta \Delta \mathrm{G}(\mathrm{kcal} / \mathrm{mol})$ & 0.87980 & 0 & 3.97780 & 4.04180 \\
\hline HOMO $(\mathrm{eV})$ & -0.30607 & -0.30606 & -0.30641 & -0.30651 \\
\hline LUMO (eV) & -0.21705 & -0.21697 & -0.21237 & -0.21226 \\
\hline$\Delta \mathrm{L}-\mathrm{H}(\mathrm{eV})$ & 0.08902 & 0.08909 & 0.09403 & 0.09425 \\
\hline $\mathrm{N}_{\mathrm{i}}$ & 39.75000 & 56.77000 & 1.79000 & 1.73000 \\
\hline
\end{tabular}

The corresponding some structural parameters such as bond lengths, bond angels and dihedral angles optimized and experimental of the possible conformers of the compound L6 in the gas phase obtained at the B3LYP theory level with $6311 \mathrm{G}++(\mathrm{d}, \mathrm{p})$ basis set are given Table 3 . To the best of our knowledge, experimental data on the geometric structure of $\mathbf{L 6}$ molecule is not available in the literature. Other bond length $(\mathrm{C}=\mathrm{N})$ in the $\mathbf{L 6}$ molecule that is calculated $1.277 \AA$ and measured $1.276 \AA$. These values are also consistent with the similar studies [22-26]. The changes in the bond length of the $\mathrm{C}-\mathrm{H}$ bond on substitution may be due to a change in the charge distribution on the carbon atom of the benzene ring [27-31]. The $\mathrm{C}-\mathrm{Cl}$ bond lengths (1.738 and $1.741 \AA)$ are in good agreement with the mean value $(1.741 \pm 0.016 \AA)$ [25]. The optimized bond lengths of $\mathrm{C}-\mathrm{H}$ and $\mathrm{C}-\mathrm{Cl}$ for B3LYP with $6-311++G(d, p)$ method were also in good agreement for similar molecules [27, 28, 30, 32].

Table 3. The selected bond lengths $(\AA)$, angles $\left(^{\circ}\right)$ and torsion angles $\left(^{\circ}\right)$ optimized and experimental of the possible conformers L6 molecule within calculated B3LYP theory level with 6$311++\mathrm{G}(\mathrm{d}, \mathrm{p})$ basis set

\begin{tabular}{|l|l|l|l|l|l|}
\hline \multirow{2}{*}{ Coordinate $^{\mathbf{a}}$} & \multicolumn{5}{|l|}{ DFT/6-31++G(d,p) } \\
\cline { 2 - 6 } & L6-1 & \multicolumn{5}{|l|}{ L6-2 } & L6-3 & L6-4 & Experimental \\
\hline Bond lengths $(\AA)$ & 1.753 & 1.753 & 1.753 & 1.753 & 1.738 \\
\hline C11-C9 & 1.762 & 1.761 & 1.747 & 1.747 & 1.741 \\
\hline C12-C10 & 1.401 & 1.407 & 1.406 & 1.406 & 1.423 \\
\hline N1-C4 & 1.277 & 1.277 & 1.274 & 1.274 & 1.276 \\
\hline N1-C5 & 1.400 & 1.402 & 1.402 & 1.403 & 1.397 \\
\hline C3-C4 & 1.400 & 1.402 & 1.402 & 1.402 & 1.398 \\
\hline C4-C12 & 1.093 & 1.093 & 1.099 & 1.099 & 0.950 \\
\hline C5-H5 & 1.471 & 1.470 & 1.470 & 1.470 & 1.473 \\
\hline C5-C6 & 1.406 & 1.406 & 1.407 & 1.403 & 1.402 \\
\hline C6-C7 & 1.404 & 1.404 & 1.410 & 1.410 & 1.398 \\
\hline C6-C10 & \multicolumn{5}{|l|}{} \\
\hline Angles ( $)$ & 120.2 & 120.2 & 119.9 & 119.8 & 119.8 \\
\hline C4-N1-C5 & 122.9 & 117.5 & 117.5 & 122.8 & 115.6 \\
\hline N1-C4-C3 & 117.8 & 123.2 & 123.1 & 117.9 & 124.8 \\
\hline N1-C4-C12 & 121.9 & 122.0 & 121.0 & 120.9 & 119.8 \\
\hline N1-C5-H5 & 121.4 & 121.4 & 125.7 & 125.8 & 120.3 \\
\hline N1-C5-C6 & 116.6 & 116.6 & 113.3 & 113.2 & 119.9 \\
\hline H5-C5-C6 & 117.4 & 117.4 & 118.1 & 118.1 & 119.0 \\
\hline C6-C7-H7 & 121.2 & 121.2 & 122.8 & 122.8 & 120.3 \\
\hline Cl2-C10-C6 & 118.9 & 120.1 & 120.0 & 118.9 & 120.3 \\
\hline C4-C12-H12 & \multicolumn{5}{|l|}{} \\
\hline
\end{tabular}


Aytekin et al. / Anadolu Univ. J. of Sci. and Technology - A - Appl. Sci. and Eng. 17 (2) - 2016

\begin{tabular}{|l|l|l|l|l|l|}
\hline Torsion angles $\left(^{\circ}\right)$ & \multicolumn{5}{|l|}{} \\
\hline $\mathrm{C} 4-\mathrm{N} 1-\mathrm{C} 5-\mathrm{H} 5$ & -3.8 & 3.8 & -3.9 & 4.0 & -0.0 \\
\hline $\mathrm{C} 4-\mathrm{N} 1-\mathrm{C} 5-\mathrm{C} 6$ & 177.1 & -177.1 & 177.8 & -177.7 & 179.9 \\
\hline $\mathrm{H} 3-\mathrm{C} 3-\mathrm{C} 4-\mathrm{N} 1$ & -1.1 & -0.8 & -0.7 & 1.02 & -0.6 \\
\hline $\mathrm{N} 1-\mathrm{C} 4-\mathrm{C} 12-\mathrm{H} 12$ & -0.8 & 1.0 & -1.1 & 0.8 & -0.5 \\
\hline $\mathrm{N} 1-\mathrm{C} 5-\mathrm{C} 6-\mathrm{C} 7$ & -1.9 & 1.7 & 173.2 & -173.7 & -17.8 \\
\hline N1-C5-C6-C10 & 178.1 & -178.4 & -6.8 & 6.3 & 163.0 \\
\hline $\mathrm{C} 5-\mathrm{C} 6-\mathrm{C} 7-\mathrm{H} 7$ & 0.0 & 0.0 & 0.3 & -0.1 & 1.5 \\
\hline $\mathrm{C} 5-\mathrm{C} 6-\mathrm{C} 10-\mathrm{Cl} 2$ & -0.1 & 0.0 & -1.1 & 0.9 & -2.8 \\
\hline
\end{tabular}

In general, calculated geometric parameters are in good agreement with those obtained from experimental results. Generally, from the theoretical values, it is found that most of the optimized bond distances are slightly longer than the experimental distances. The small differences may be due to that the theoretical calculations belong to isolates molecules in gaseous phase without any intermolecular interactions and the experimental results belong to molecules in solid state.

\subsection{Electronic Spectra}

The highest occupy molecular orbitals (HOMO) and the lowest unoccupied molecular orbitals (LUMO) are called as frontier molecular orbitals (FMOs). HOMO (H) and LUMO (L) are the most important orbitals in molecules and the energy gap between HOMO and LUMO is a useful parameter in determining the optical and electrical properties. Based on the optimized structure, the surfaces of HOMO and LUMO calculated using DFT method at B3LYP/6-311++G(d,p) base set in gaseous phase were given in Figure 3. In Figure 3, the positive and negative phase were represented in red and green color, respectively. The energies of HOMO and LUMO orbitals of the title compound in gas phase are $-0.30606,-0.21697 \mathrm{eV}$ respectively. The HOMO and LUMO orbital energy gap is equal (energy gap=LUMO-HOMO) $+0.08909 \mathrm{eV}$ and explains the possible charge transfer interactions taking place within the molecule.

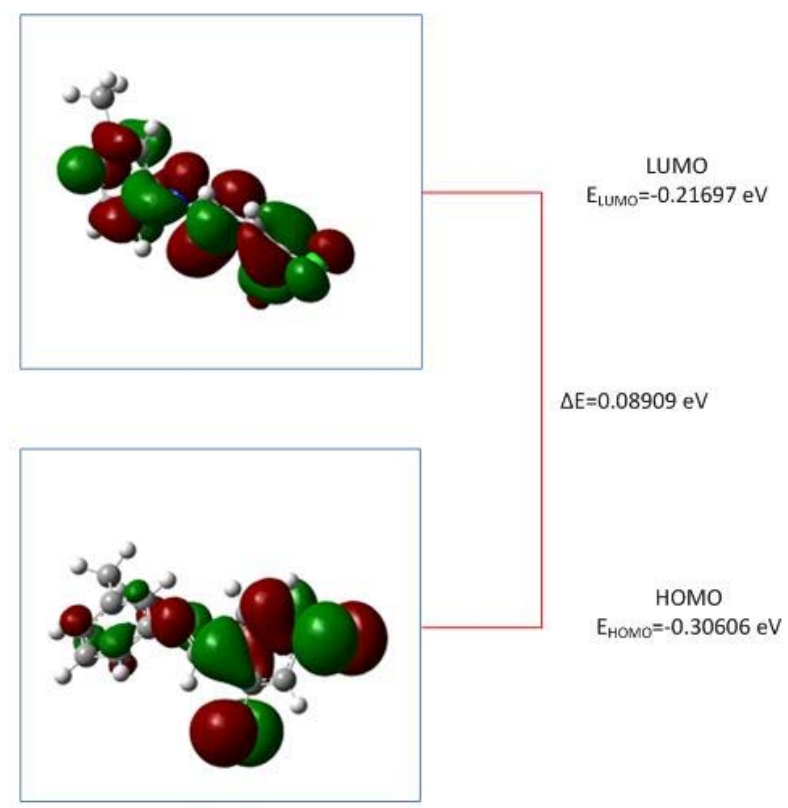

Figure 3. Highest occupied and lowest unoccupied orbitals of $\mathbf{L 6}$

The UV-Vis spectrum provide the most detailed information about the electronic structure of a compound. The UV-Vis spectrum of the ligand was recorded in ethanol at room temperature. The experimental and theoretical UV-Vis spectra of $\mathbf{L 6}$ in ethanol solvent are given in Figure 4 (a) and (b). Generally, in the electronic absorption spectra of Schiff base compounds the bands $(300-400 \mathrm{~nm})$ 
Aytekin et al. / Anadolu Univ. J. of Sci. and Technology - A - Appl. Sci. and Eng. 17 (2) - 2016

show azomethine $\mathrm{C}=\mathrm{N}$ group. The first bands at higher energy $(200-300 \mathrm{~nm})$ are attributed to $\pi-\pi *$ transitions associated with the phenyl ring and the second bands at lower energy are related to $\pi-\pi *$ transitions associated with the azomethine group. In the molecule, the band in the region 300$400 \mathrm{~nm}$ is attributed to the $\mathrm{n}-\pi *$ transition. The calculated absorption wavelengths $\left(\lambda_{\max }\right)$ are in good agreement with the experimental values. These values are similar to those found in related Schiff base compounds $[2,4]$.

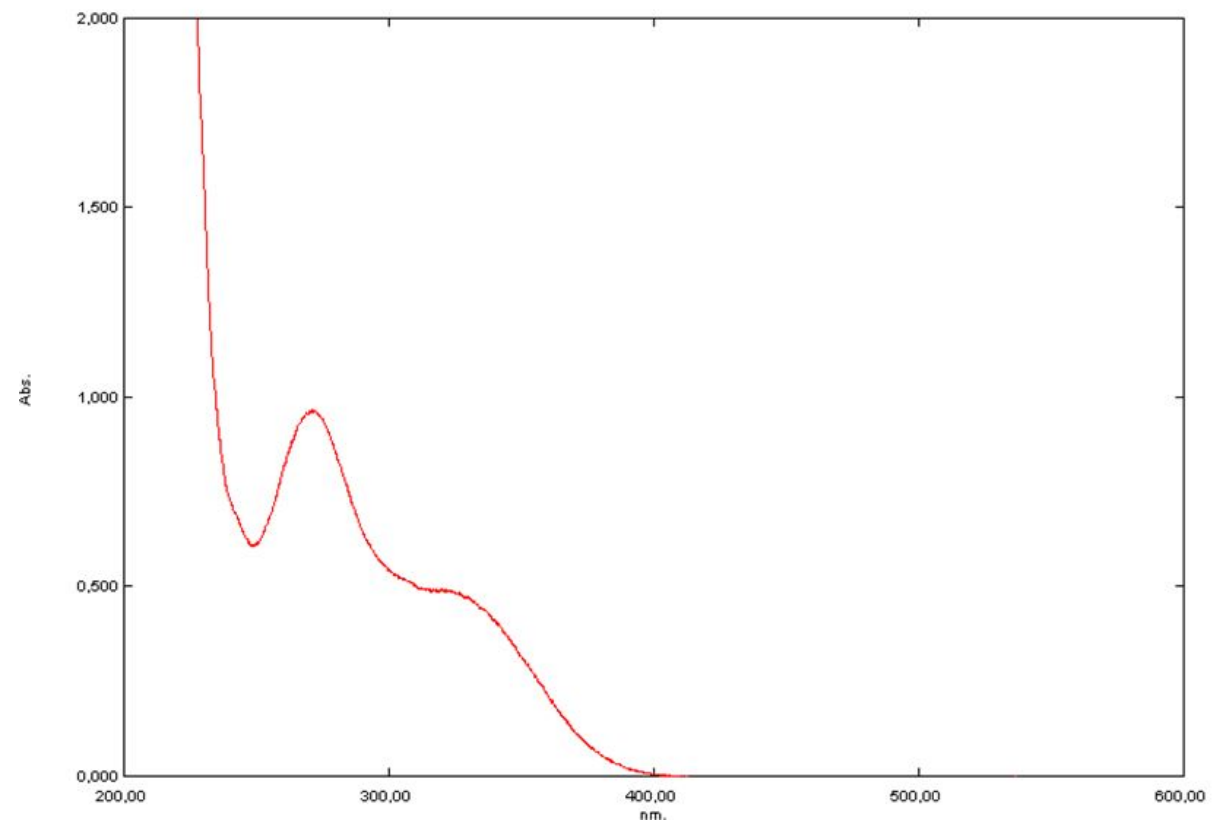

(a)

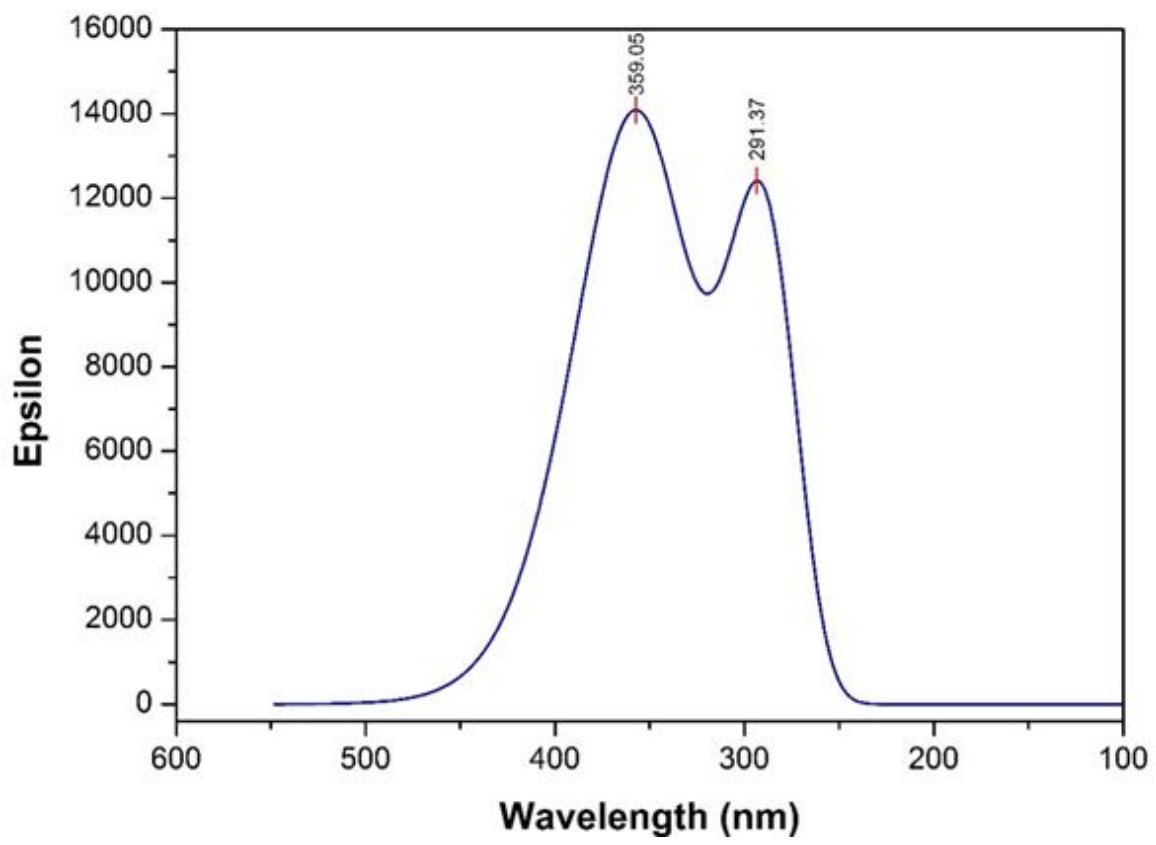

(b)

Figure 4 (a) The experimental and (b) theoretical UV-Vis spectra of L6 in ethanol solvent 
Aytekin et al. / Anadolu Univ. J. of Sci. and Technology - A - Appl. Sci. and Eng. 17 (2) - 2016

\subsection{Vibrational Spectral Analysis}

To the best of our knowledge, there is no detailed quantum chemical study for the molecular structure and vibrational spectra of $\mathbf{L 6}$ molecule. The assignments of the normal vibrational modes of the most stable conformer of investigated compound along with the observed fundamentals, unscaled frequencies obtained by B3LYP/6-311++G(d,p) calculations and scaled frequencies as well as the PED descriptions are given in Table 4. The experimental and theoretical infrared and Raman spectra of $\mathbf{L 6}$ compound were presented in Figure 5 and 6 for comparative purposes. The $\mathbf{L 6}$ molecule consist of 28 atoms, which have 78 normal modes of fundamental vibrations and it belongs to $\mathrm{C} 1$ symmetry group. In order to simplify the experimental assignment as much as possible, it is necessary to clarify characteristic group vibrations.

The aromatic structure shows the presence of C-H stretching vibrations in the region $3000-3100 \mathrm{~cm}^{-1}$ which is the characteristic region for ready identification of $\mathrm{C}-\mathrm{H}$ stretching vibrations [33-35]. Accordingly, in the present study the FT-IR bands at 3058, $3026 \mathrm{~cm}^{-1}$ and Raman bands at 3099, 3073 $\mathrm{cm}^{-1}$ are assigned to the $\mathrm{C}-\mathrm{H}$ stretching vibrations of the title compound. The bands at 2994, 2940, 2918 and $2859 \mathrm{~cm}^{-1}$ in FT-IR spectrum and $2928 \mathrm{~cm}^{-1}$ in Raman spectrum are attributed to the C-H stretching vibrations. The corresponding scaled calculated frequencies of $\mathrm{CH}$ stretching vibrations at 2973, 2948, 2946 and $2896 \mathrm{~cm}^{-1}$ are good agreement with the experimental data. The CH in-plane bending vibrations, the vibrational bands of the sample were observed at 1170, 1146, 1135 and 1098 $\mathrm{cm}^{-1}$ in infrared spectrum and 1066, $1011 \mathrm{~cm}^{-1}$ in Raman spectrum. The $\mathrm{CH}$ out-of-plane deformation vibrations of L6 were recorded at 972, 963, 953, 927, 896, 868 and $763 \mathrm{~cm}^{-1}$ in infrared spectrum and $885 \mathrm{~cm}^{-1}$ in Raman spectrum. The characteristic band of L6 compound which contain azomethine group was observed at 1598 and $1610 \mathrm{~cm}^{-1}$ in the FT-IR and Raman spectrum respectively. The vibrational spectra of the compound also showed several bands corresponding to aromatic $\mathrm{CC}$ stretching, HCC and HCN bending and some torsion bands. The vibrations belonging to the bond between the ring and the halogen atoms are also observed below $900 \mathrm{~cm}^{-1}$. Ring stretching and $\mathrm{CH}$ bending modes show the $1500-1000 \mathrm{~cm}^{-1}$ region of the Raman spectrum. The above conclusions are in very good agreement with literature values $[19,24,26,27,30,33,36-40]$. 
Aytekin et al. / Anadolu Univ. J. of Sci. and Technology - A - Appl. Sci. and Eng. 17 (2) - 2016

Table 4 The vibrational wavenumbers $\left(\mathrm{cm}^{-1}\right)$ of $\mathbf{L 6}$

\begin{tabular}{|c|c|c|c|c|c|c|c|}
\hline \multirow[b]{2}{*}{ Mode } & \multicolumn{2}{|c|}{ Experimental } & \multicolumn{4}{|c|}{ B3LYP/6-311++G(d,p) } & \multirow[b]{2}{*}{ P.E.D.s $\geq 5$} \\
\hline & IR (Nujol) & Raman (solid) & $v^{\mathbf{b}}$ & $v^{c}$ & $\mathbf{I}_{I^{\prime}}{ }^{d}$ & $\mathbf{I}_{\mathbf{R}^{\mathbf{d}}}$ & \\
\hline 1 & $3058 \mathrm{w}$ & $3099 \mathrm{vw}$ & 3172 & 3039 & 19.05 & 127.13 & $v \mathrm{CH}(90)$ \\
\hline 2 & $3026 \mathrm{vw}$ & $3073 \mathrm{w}$ & 3158 & 3025 & 3.64 & 73.17 & $\mathrm{vCH}(96)$ \\
\hline 3 & $2994 \mathrm{vw}$ & - & 3103 & 2973 & 15.68 & 72.61 & $v \mathrm{CH}(99)$ \\
\hline 4 & $2940 \mathrm{vw}$ & - & 3077 & 2948 & 17.81 & 106.04 & $\mathrm{vCH}(97)$ \\
\hline 5 & $2918 \mathrm{w}$ & - & 3075 & 2946 & 23.03 & 26.86 & vCH(96) \\
\hline 6 & $2859 \mathrm{vw}$ & $2928 \mathrm{w}$ & 3023 & 2896 & 34.22 & 315.37 & $v \mathrm{CH}(100)$ \\
\hline 7 & $1598 \mathrm{~m}$ & $1610 \mathrm{~s}$ & 1677 & 1649 & 35.31 & 2409.10 & $v \mathrm{CN}(67)$ \\
\hline 8 & $1583 \mathrm{~s}$ & - & 1637 & 1609 & 43.20 & 617.65 & $v \mathrm{CC}(41)$ \\
\hline 9 & - & $1582 \mathrm{vs}$ & 1619 & 1592 & 106.07 & 1708.94 & $v \mathrm{CC}(24)$ \\
\hline 10 & $1553 \mathrm{~m}$ & - & 1607 & 1580 & 56.69 & 2424.21 & $v \mathrm{CC}(43)+\delta \mathrm{HCC}(12)$ \\
\hline 11 & $1519 \mathrm{vw}$ & - & 1583 & 1556 & 22.84 & 205.54 & $v \mathrm{vC}(50)+\delta \mathrm{HCC}(10)$ \\
\hline 12 & $1471 \mathrm{~s}$ & $1484 \mathrm{vw}$ & 1514 & 1488 & 51.45 & 76.60 & $\delta \mathrm{HCC}(48)$ \\
\hline 13 & - & $1436 \mathrm{vw}$ & 1495 & 1470 & 30.70 & 148.42 & $\delta \mathrm{HCC}(41)+\delta \mathrm{HCH}(23)$ \\
\hline 14 & $1417 \mathrm{vw}$ & - & 1490 & 1465 & 7.75 & 11.20 & $\delta \mathrm{HCH}(78)+\tau \mathrm{HCCC}(11)$ \\
\hline 15 & $1385 \mathrm{~s}$ & $1395 \mathrm{w}$ & 1454 & 1429 & 2.68 & 90.58 & $\mathrm{vCC}(30)$ \\
\hline 16 & $1371 \mathrm{vw}$ & $1376 \mathrm{w}$ & 1415 & 1391 & 1.26 & 38.01 & $\delta \mathrm{HCH}(91)$ \\
\hline 17 & $1361 \mathrm{~s}$ & - & 1412 & 1388 & 26.04 & 394.85 & $v C C(33)+\delta H C C(29)$ \\
\hline 18 & $1328 \mathrm{vw}$ & - & 1397 & 1373 & 22.35 & 67.15 & $\delta \mathrm{HCN}(60)$ \\
\hline 19 & $1284 \mathrm{vw}$ & $1301 \mathrm{w}$ & 1341 & 1318 & 1.79 & 13.89 & $v \mathrm{CC}(37)+\delta \mathrm{HCC}(50)$ \\
\hline 20 & $1272 \mathrm{w}$ & $1258 \mathrm{~m}$ & 1316 & 1294 & 4.42 & 137.85 & $v C C(23)$ \\
\hline 21 & $1261 \mathrm{w}$ & & 1303 & 1281 & 1.57 & 5.39 & $v \mathrm{CC}(39)$ \\
\hline 22 & $1245 \mathrm{w}$ & $1255 \mathrm{~m}$ & 1288 & 1266 & 9.50 & 121.86 & $v \mathrm{CC}(14)+\delta \mathrm{HCC}(41)$ \\
\hline 23 & $1209 \mathrm{w}$ & $1150 \mathrm{~s}$ & 1271 & 1249 & 13.01 & 701.49 & $v \mathrm{CN}(15)+v \mathrm{CC}(12)+\delta \mathrm{HCC}(13)$ \\
\hline 24 & $1170 \mathrm{vw}$ & - & 1229 & 1208 & 9.61 & 543.12 & $\mathrm{vCC}(35)+\delta \mathrm{HCC}(15)$ \\
\hline 25 & $1146 \mathrm{w}$ & - & 1192 & 1172 & 0.12 & 18.99 & $\delta \mathrm{HCC}(73)+v \mathrm{CC}(14)$ \\
\hline 26 & $1135 \mathrm{~m}$ & $1066 \mathrm{vw}$ & 1171 & 1151 & 2.80 & 149.16 & $v \mathrm{CN}(15)+v \mathrm{CC}(11)+\delta \mathrm{HCC}(29)$ \\
\hline 27 & $1098 \mathrm{~s}$ & $1011 \mathrm{w}$ & 1149 & 1130 & 34.96 & 580.16 & $v C C(12)+\delta \mathrm{HCC}(38)$ \\
\hline 28 & $1050 \mathrm{~s}$ & $940 \mathrm{vw}$ & 1110 & 1091 & 68.39 & 72.86 & $v \mathrm{CC}(53)+v \mathrm{ClC}(12)$ \\
\hline 29 & $1000 \mathrm{w}$ & - & 1062 & 1044 & 23.27 & 2.27 & $\delta \mathrm{CCC}(32)+\tau \mathrm{HCCC}(16)$ \\
\hline 30 & $972 \mathrm{~m}$ & $885 \mathrm{vw}$ & 1021 & 1004 & 6.48 & 21.44 & $\tau \mathrm{HCCC}(42)$ \\
\hline 31 & $963 \mathrm{vw}$ & - & 1015 & 998 & 1.40 & 42.14 & $\delta \mathrm{CCC}(53)+\tau \mathrm{HCNC}(15)$ \\
\hline 32 & $953 \mathrm{~m}$ & - & 1005 & 989 & 5.53 & 151.98 & $\tau \mathrm{HCNC}(41)+\tau \mathrm{HCCC}(14)$ \\
\hline 33 & $927 \mathrm{w}$ & - & 947 & 931 & 17.54 & 47.63 & $\delta \mathrm{CCC}(24)+v \mathrm{CN}(15)+v \mathrm{CC}(13)$ \\
\hline 34 & $896 \mathrm{~s}$ & - & 918 & 902 & 7.88 & 1.47 & $\tau \mathrm{HCCC}(72)$ \\
\hline 35 & $868 \mathrm{vs}$ & - & 879 & 864 & 41.34 & 29.69 & $\delta \mathrm{CCC}(38)$ \\
\hline 36 & 825 vs & - & 843 & 829 & 23.58 & 1.93 & $\tau \mathrm{HCCC}(74)$ \\
\hline 37 & $794 \mathrm{~m}$ & - & 805 & 791 & 22.10 & 13.36 & $\tau \mathrm{HCCC}(26)+v \mathrm{ClC}(10)$ \\
\hline 38 & $769 \mathrm{vs}$ & - & 787 & 774 & 40.56 & 7.64 & $\tau \mathrm{HCCC}(49)$ \\
\hline 39 & $763 \mathrm{vs}$ & $742 \mathrm{vw}$ & 738 & 725 & 18.23 & 7.54 & $v \mathrm{VCC}(12)+\delta \mathrm{CCC}(12)$ \\
\hline 40 & $731 \mathrm{~m}$ & - & 728 & 716 & 3.03 & 1.72 & $\tau \mathrm{CCCC}(68)$ \\
\hline 41 & $707 \mathrm{vs}$ & - & 706 & 694 & 16.74 & 0.78 & $\tau \mathrm{HCCC}(25)+\tau \operatorname{CCCC}(27)$ \\
\hline 42 & $682 \mathrm{vs}$ & $680 \mathrm{w}$ & 676 & 665 & 1.00 & 21.16 & $\delta \mathrm{CCC}(54)+v \mathrm{CC}(12)$ \\
\hline 43 & $609 \mathrm{~m}$ & $624 \mathrm{vw}$ & 618 & 607 & 4.09 & 5.29 & $v \mathrm{CC}(14)+v \mathrm{ClC}(15)+\delta \mathrm{CCC}(23)$ \\
\hline 44 & $576 \mathrm{~m}$ & - & 596 & 586 & 2.34 & 8.87 & $\tau \mathrm{CCCC}(12)+\tau \mathrm{NCCC}(12)$ \\
\hline 45 & $554 \mathrm{w}$ & - & 573 & 563 & 4.90 & 0.62 & $\tau \mathrm{HCCC}(14)+\tau \mathrm{CCCC}(14)+\tau \operatorname{ClCCC}(25)$ \\
\hline 46 & $545 \mathrm{~m}$ & $531 \mathrm{w}$ & 529 & 520 & 0.34 & 6.32 & $\delta \operatorname{CCC}(29)+v \operatorname{CC}(12)$ \\
\hline 47 & $516 \mathrm{w}$ & - & 520 & 511 & 2.80 & 6.63 & $\delta \mathrm{CCC}(26)+\delta \mathrm{NCC}(18)$ \\
\hline 48 & $461 \mathrm{w}$ & - & 472 & 464 & 7.99 & 1.18 & $\tau \mathrm{CCCC}(37)+\tau \mathrm{ClCCC}(12)$ \\
\hline 49 & $445 \mathrm{~s}$ & $465 \mathrm{vw}$ & 451 & 443 & 12.19 & 12.68 & $\tau \operatorname{CCCC}(16)+\tau \operatorname{CCCC}(12)$ \\
\hline 50 & $438 \mathrm{w}$ & - & 448 & 440 & 5.10 & 0.12 & $\tau \mathrm{CCCC}(15)$ \\
\hline 51 & $408 \mathrm{w}$ & $429 \mathrm{vw}$ & 418 & 411 & 9.21 & 13.38 & $v \mathrm{ClC}(30)+\delta \mathrm{CCC}(10)$ \\
\hline
\end{tabular}

${ }^{\mathrm{a}}$ vs: very strong, s: strong, m: medium, w: weak, vw: very weak, br: broad, sh: shoulder. $v, \delta$ and $\tau$ denote stretching, bending and torsion modes, respectively.

${ }^{\text {bUnscaled values }}$

'Scaled values. Scaled with 0.958 above $1700 \mathrm{~cm}^{-1}, 0.983$ under $1700 \mathrm{~cm}^{-1}$.

${ }^{\mathbf{d}} \mathrm{I}_{\mathrm{IR}}$ and $\mathrm{I}_{\mathrm{R}}$ : calculated infrared intensities and Raman activities. PED data are taken from VEDA4 [26]. 
Aytekin et al. / Anadolu Univ. J. of Sci. and Technology - A - Appl. Sci. and Eng. 17 (2) - 2016

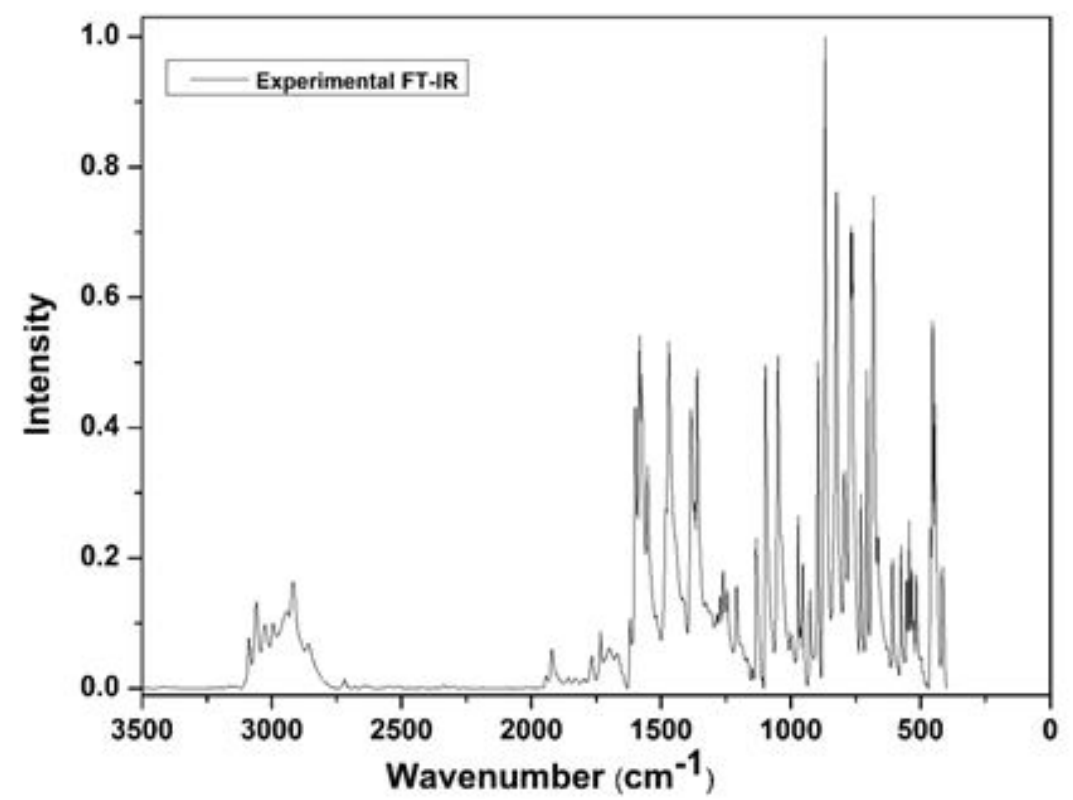

(a)

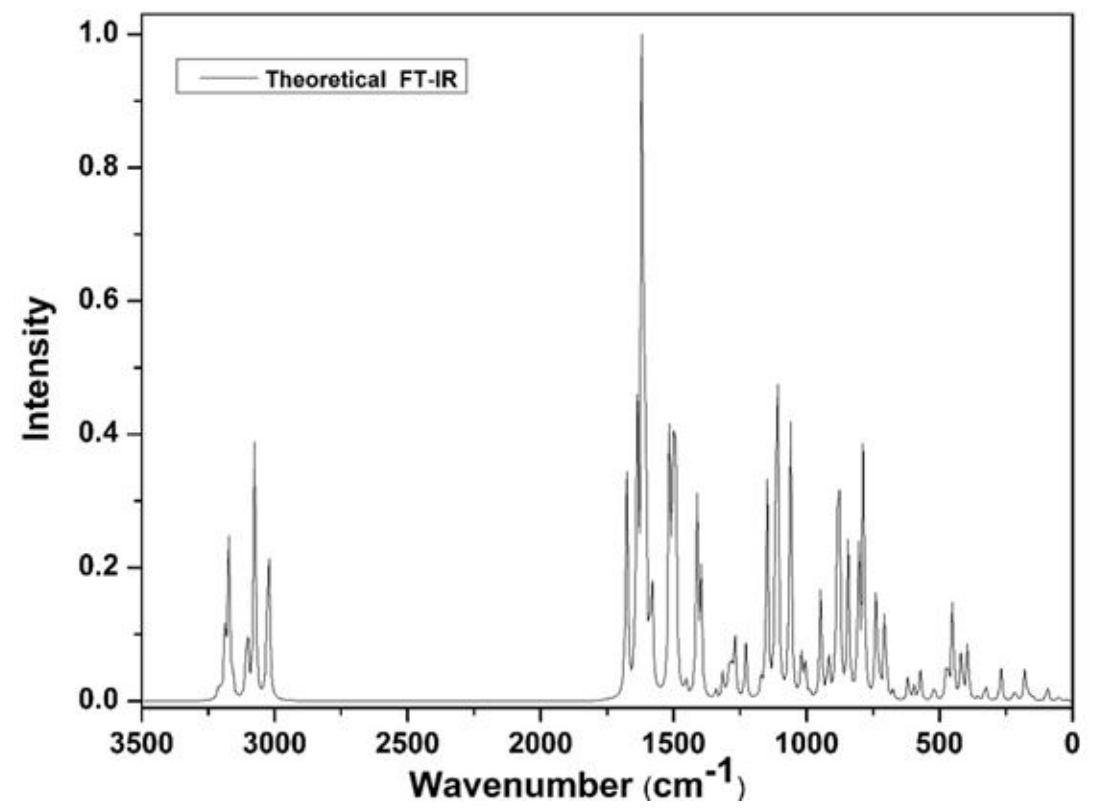

(b)

Figure 5 (a) Experimental and (b) theoretical infrared spectra of L6 
Aytekin et al. / Anadolu Univ. J. of Sci. and Technology - A - Appl. Sci. and Eng. 17 (2) - 2016

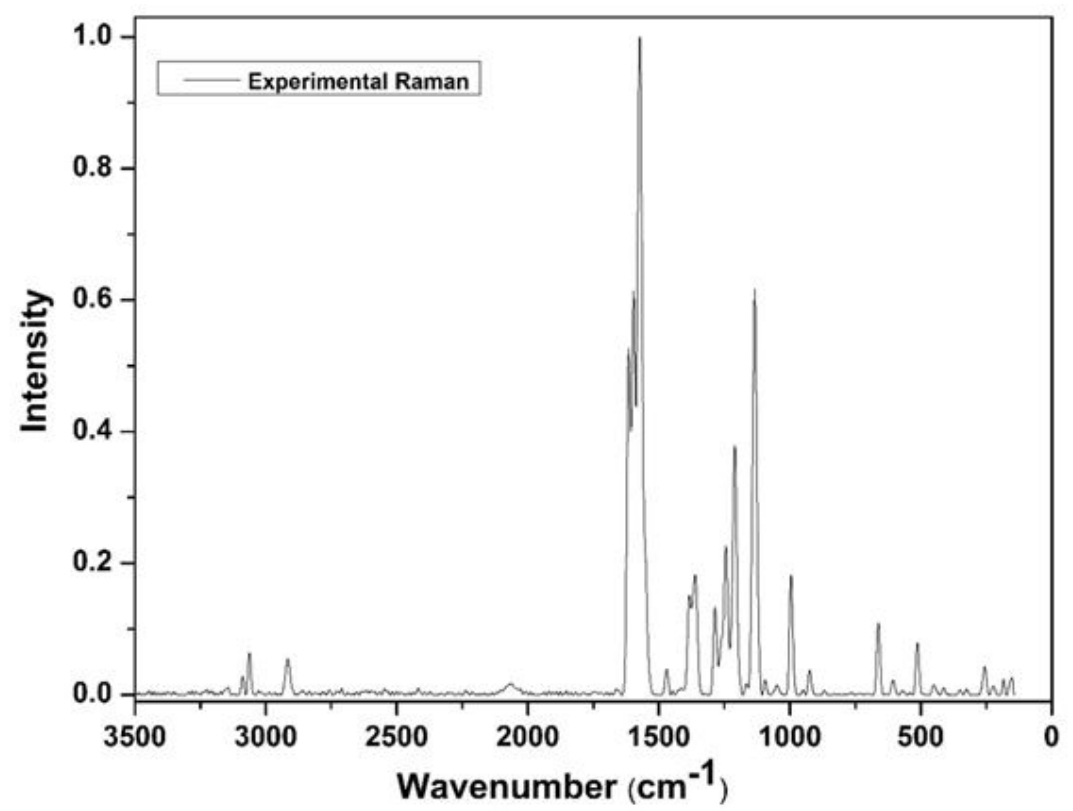

(a)

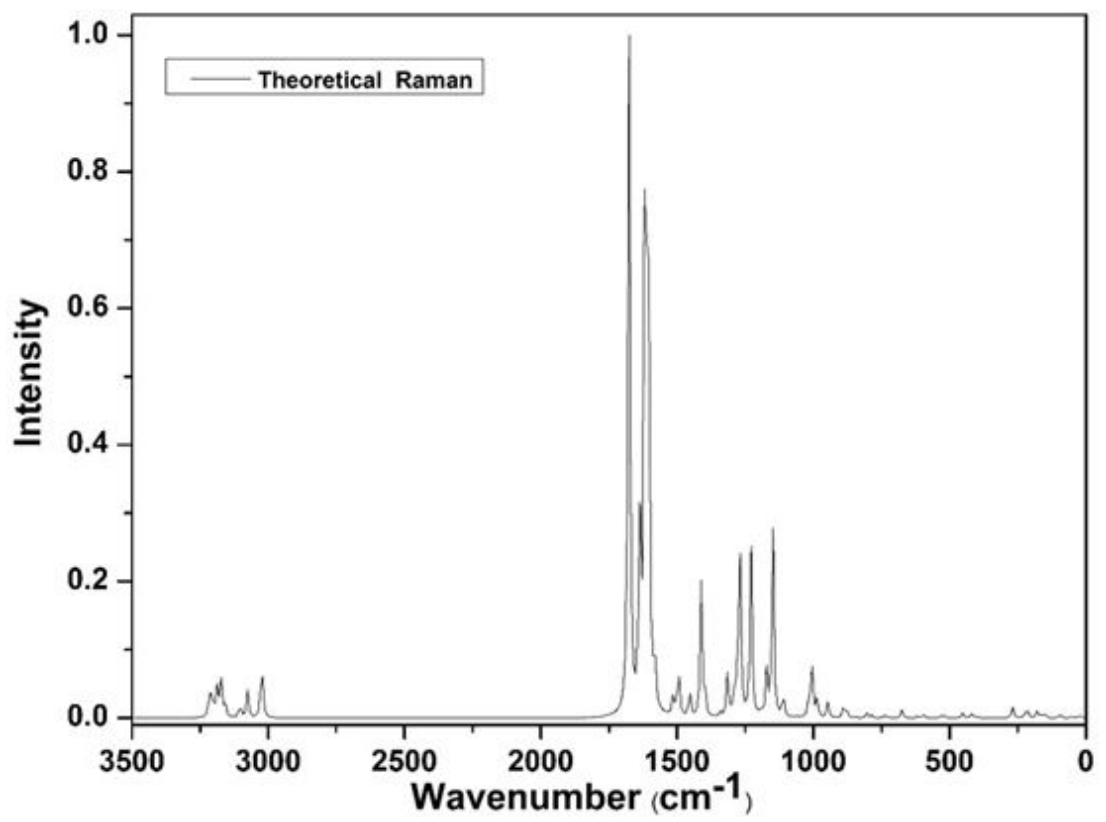

(b)

Figure 6 Experimental (a) and theoretical (b) Raman spectra of L6

The correlation between the experimental and calculated wavenumbers can be seen by plotting the calculated versus experimental wavenumbers (for infrared and Raman). The correlation graphics were plotted in Figure 7 (a) and (b) for infrared and Raman, respectively, based on the DFT/B3LYP method. As can be seen from Figure 7, the relations are usually linear and described by Equations 1 and 2: 
Aytekin et al. / Anadolu Univ. J. of Sci. and Technology - A - Appl. Sci. and Eng. 17 (2) - 2016

$$
\begin{aligned}
& v_{\text {cal. }}=0.9797 v_{\text {exp. }}+36.875\left(\mathrm{R}^{2}=0.9964 \text { for infrared }\right) \\
& v_{\text {cal. }}=1.0038 v_{\text {exp. }}+6.3857\left(\mathrm{R}^{2}=0.9994 \text { for Raman }\right)
\end{aligned}
$$

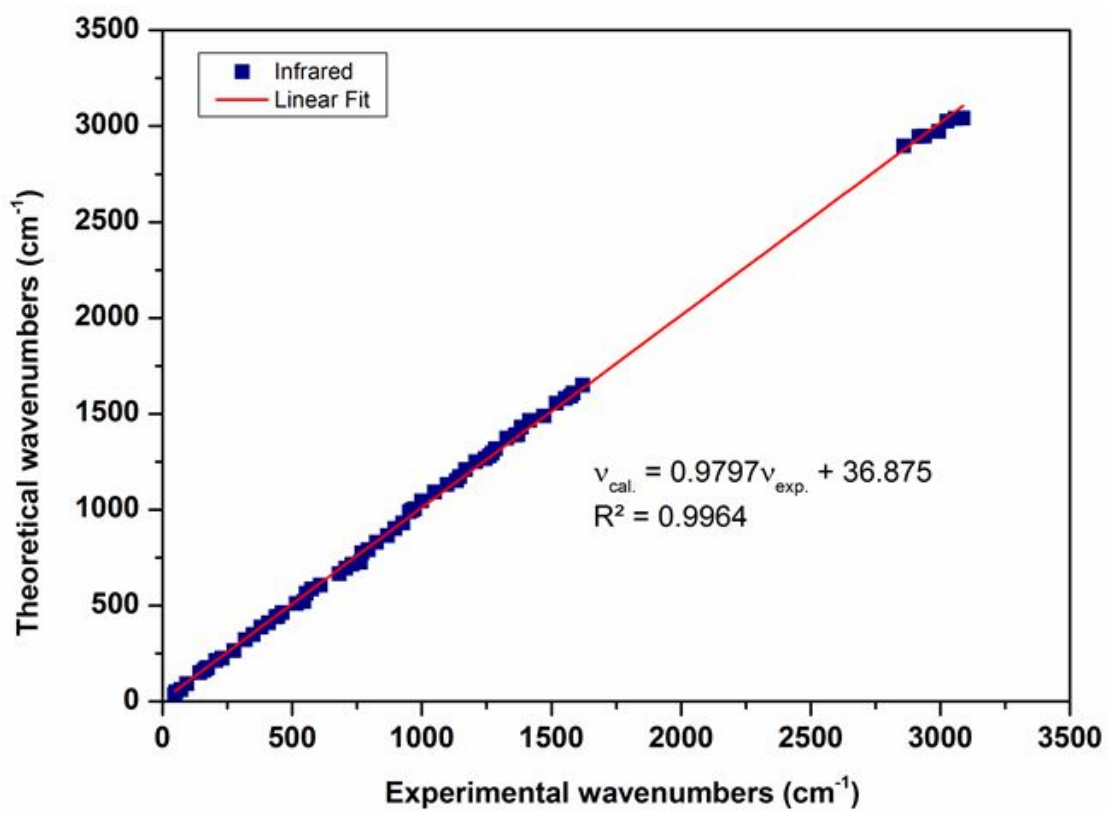

(a)

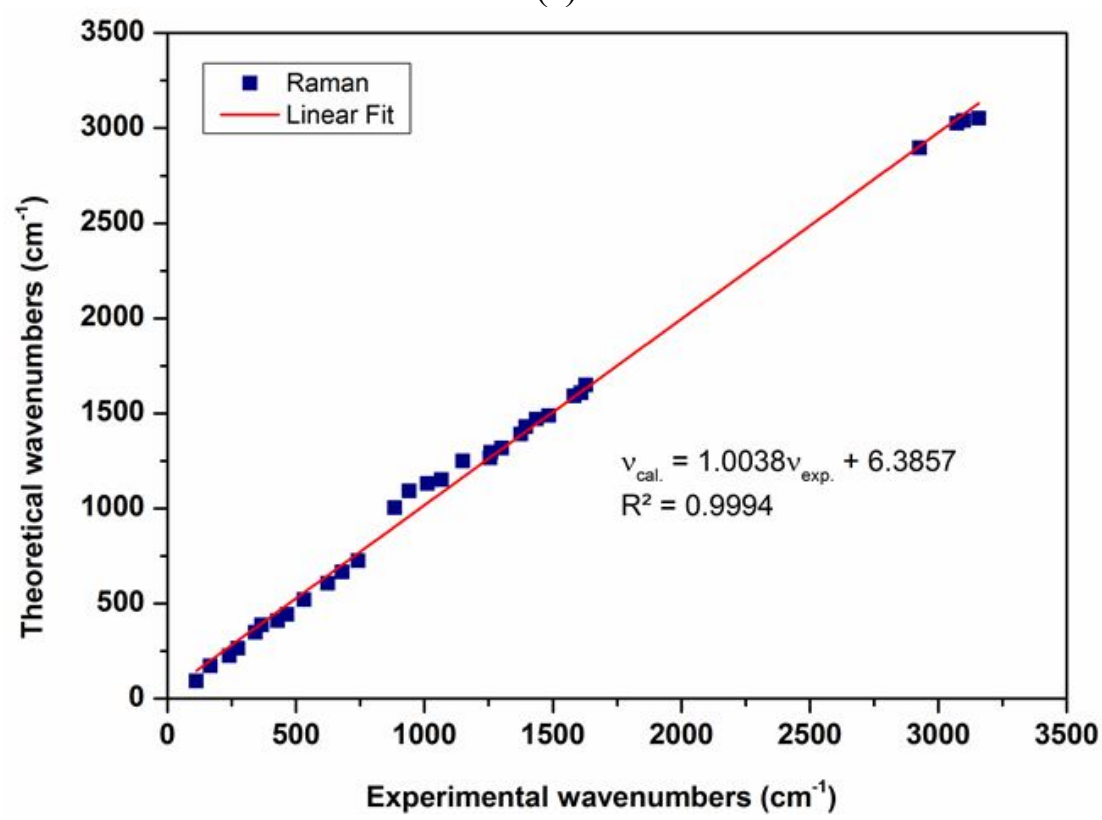

(b)

Figure 7 The correlation graphics of experimental (a) and calculated (b) wavenumbers of $\mathbf{L 6}$

\section{6. ${ }^{1} \mathrm{H}$ and ${ }^{13} \mathrm{C}$ NMR Chemical Shift Assignment}

The experimental and theoretical ${ }^{1} \mathrm{H}$ and ${ }^{13} \mathrm{C}$ NMR spectra of the title compound are shown in Figure 8 and Figure 9, respectively. ${ }^{13} \mathrm{C}$ NMR spectrum of the compound exhibited characteristic peak in the region $21.69 \mathrm{ppm}$ assignable to the methylene groups and singlets over the range 121.70-160.24 ppm characteristic of the aromatic groups. Aromatic ring protons (in the region ca. 7.19 and $9.10 \mathrm{ppm}$ ), 
Aytekin et al. / Anadolu Univ. J. of Sci. and Technology - A - Appl. Sci. and Eng. 17 (2) - 2016

methyl protons (at $c a .2 .36 \mathrm{ppm}$ ) and methylene protons (in the region 2.7-3.5 ppm) in proton NMR, clearly indicating the aromatic and methyl hydrogens. Table 5 and 6 shows the ${ }^{13} \mathrm{C}$ and ${ }^{1} \mathrm{H}$ NMR chemical shifts (ppm) for the compound.

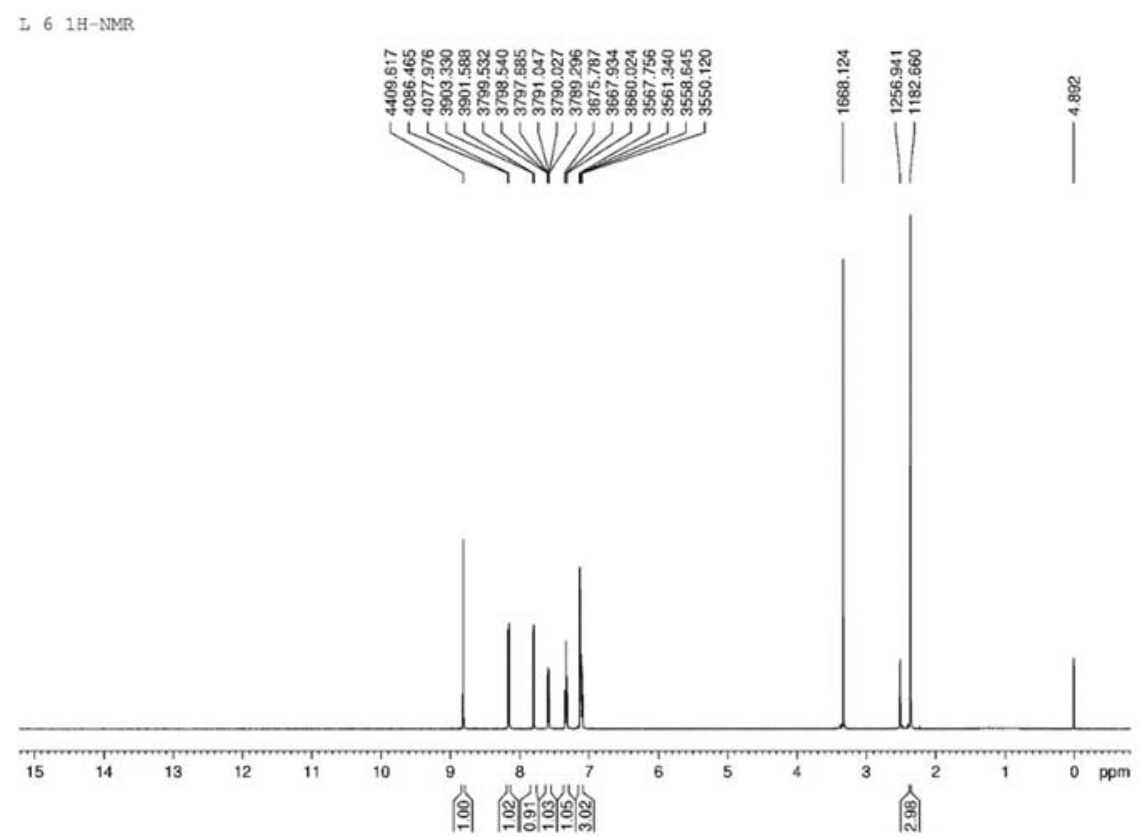

(a)

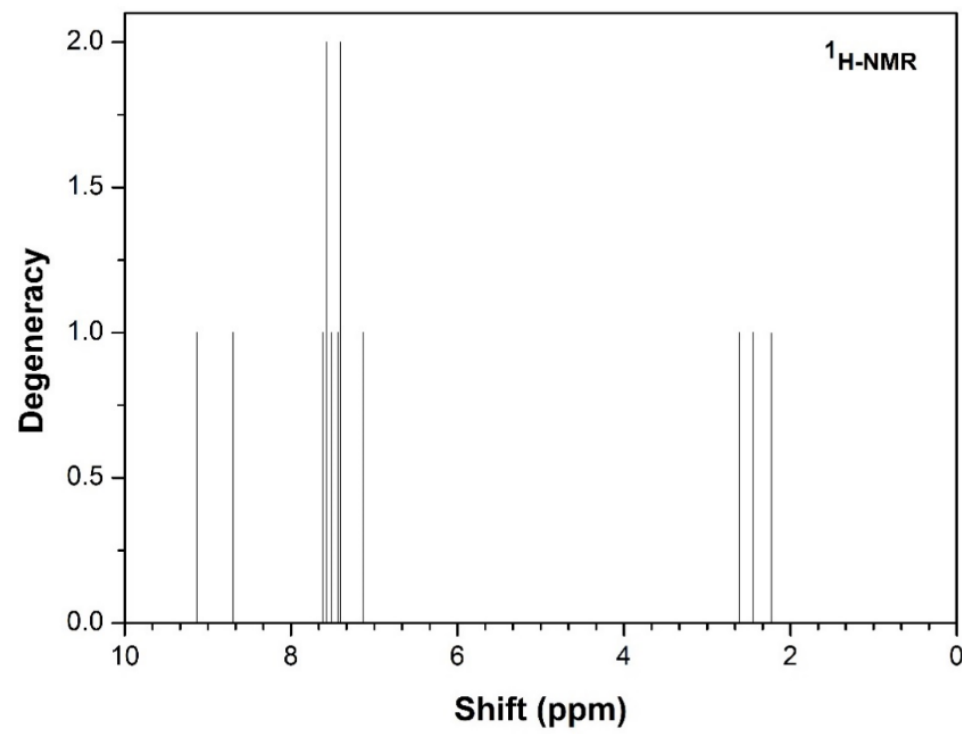

(b)

Figure 8 (a) Experimental and (b) theoretical ${ }^{1} \mathrm{H}-\mathrm{NMR}$ spectra of $\mathbf{L 6}$

The theoretical ${ }^{1} \mathrm{H}$ and ${ }^{13} \mathrm{C}$ NMR chemical shifts at the B3LYP/6-311++G(d,p) levels of theory along with experimental data are given in Table 5 and Table 6, respectively. As can be seen, the theoretical results are in very good agreement with the experimental data. Compared with the experimental ${ }^{1} \mathrm{H}$ NMR chemical shifts, correlation graphic based on the theoretical shifts is presented in Figure 10. The correlation graphic between experimental and calculated ${ }^{13} \mathrm{C}$ NMR chemical shift is shown in Figure 11. The ${ }^{1} \mathrm{H}$ and ${ }^{13} \mathrm{C}$ NMR chemical shifts correlation values are 0.9893 and 0.9856 , respectively. 
Aytekin et al. / Anadolu Univ. J. of Sci. and Technology - A - Appl. Sci. and Eng. 17 (2) - 2016

Table 5 Theoretical and experimental ${ }^{1} \mathrm{H}$ NMR chemical shifts (all values in ppm) of $\mathbf{L 6}$

\begin{tabular}{|l|l|l|}
\hline Experimental & DFT/B3LYP & Assignment \\
\hline 9.104 & 8.82 & $21-\mathrm{H}$ \\
\hline 8.683 & 8.17 & $19-\mathrm{H}$ \\
\hline 7.6263 & 7.81 & $18-\mathrm{H}$ \\
\hline 7.5541 & 7.60 & $20-\mathrm{H}$ \\
\hline 7.5071 & 7.35 & $23-\mathrm{H}$ \\
\hline 7.3952 & 7.33 & $24-\mathrm{H}$ \\
\hline 7.3518 & 7.31 & $22-\mathrm{H}$ \\
\hline 7.1976 & 7.13 & $25-\mathrm{H}$ \\
\hline 2.3671 & 2.37 & $26-\mathrm{H}, 27-\mathrm{H}, 28 \mathrm{H}$ \\
\hline
\end{tabular}

Table 6 Theoretical and experimental ${ }^{13} \mathrm{C}$ NMR chemical shifts (all values in ppm) of $\mathbf{L 6}$

\begin{tabular}{|l|l|l|}
\hline Experimental & DFT/B3LYP & Assignment \\
\hline 160.2431 & 155.5 & $7-\mathrm{C}$ \\
\hline 159.0383 & 151.34 & $9-\mathrm{C}$ \\
\hline 151.6762 & 139.25 & $13-\mathrm{C}$ \\
\hline 151.0816 & 137.14 & $4-\mathrm{C}$ \\
\hline 147.3748 & 136.21 & $11-\mathrm{C}$ \\
\hline 147.3748 & 132.18 & $3-\mathrm{C}$ \\
\hline 134.8123 & 130.14 & $5-\mathrm{C}$ \\
\hline 134.3862 & 130.10 & $1-\mathrm{C}$ \\
\hline 133.5209 & 130.04 & $12-\mathrm{C}$ \\
\hline 132.5112 & 129.64 & $2-\mathrm{C}$ \\
\hline 132.1146 & 128.54 & $6-\mathrm{C}$ \\
\hline 126.9945 & 127.92 & $14-\mathrm{C}$ \\
\hline 121.7082 & 118.76 & $10-\mathrm{C}$ \\
\hline 21.6964 & 21.41 & $15-\mathrm{C}$ \\
\hline
\end{tabular}

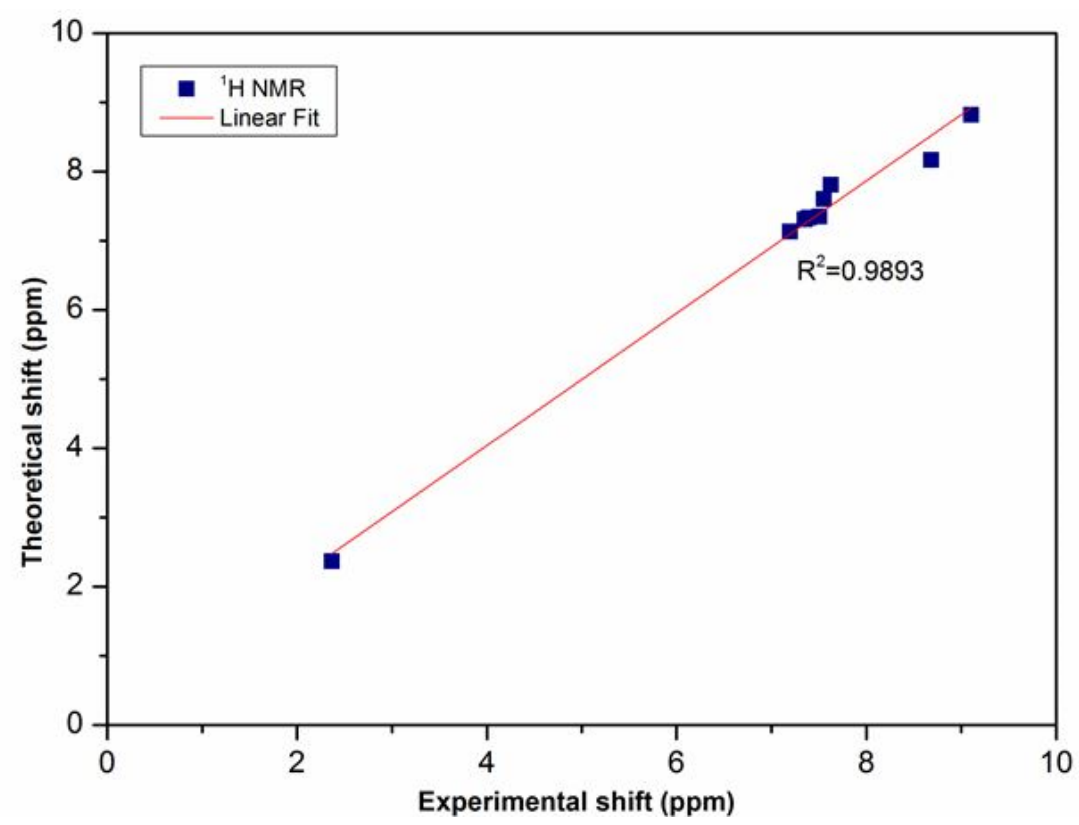

Figure 10 The correlation graph of experimental and calculated ${ }^{1} \mathrm{H}$ NMR chemical shifts of $\mathbf{L 6}$ 
Aytekin et al. / Anadolu Univ. J. of Sci. and Technology - A - Appl. Sci. and Eng. 17 (2) - 2016

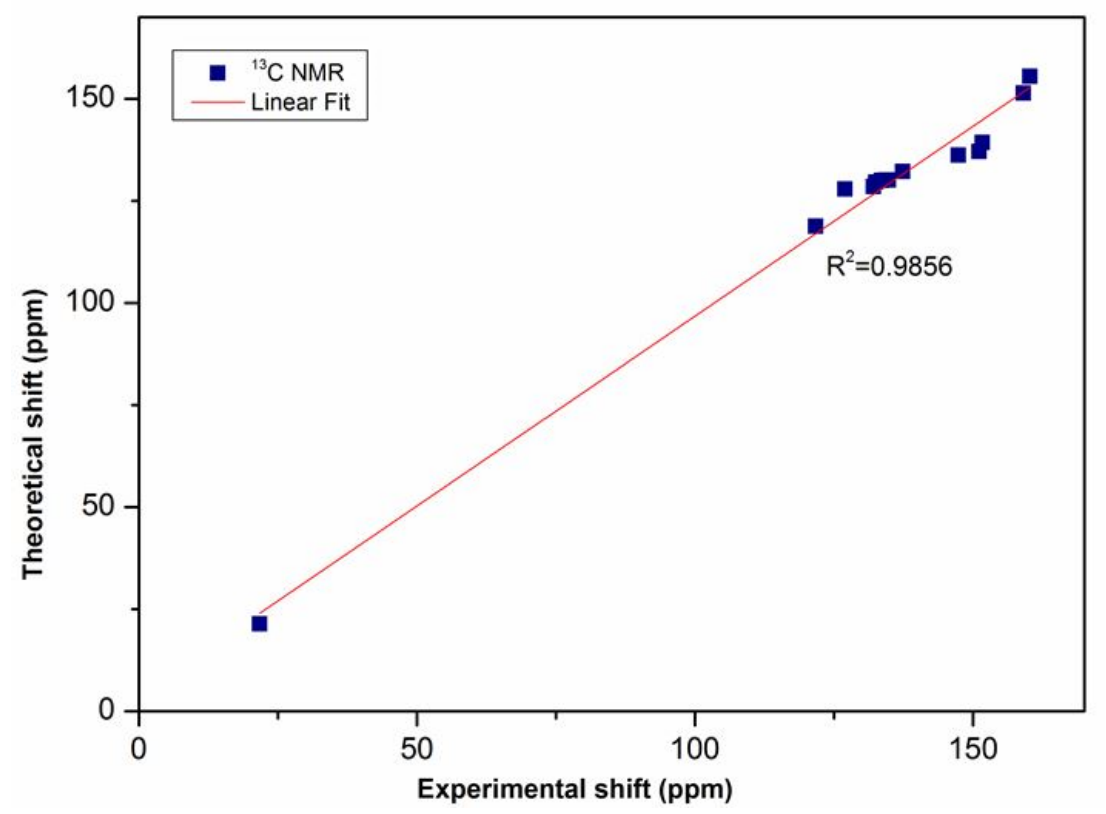

Figure 11 The correlation graph of experimental and calculated ${ }^{13} \mathrm{C}$ NMR chemical shifts of $\mathbf{L 6}$

\subsection{Thermal Analysis}

The thermal stability of the title was analyzed by thermogravimetric analysis (TGA). The weight loss profiles are analyzed by the amount or percent of weight loss at any given temperature. Thermogravimetric analysis (TGA) and differential thermal analysis (DTA) curves of L are presented in Figure 12. The TGA curve of $\mathrm{L}$ displays four stages of mass loss within the temperature range of 0 $1400{ }^{\circ} \mathrm{C}$. The TG curve of ligand L6, refers to two stages of mass losses at temperature ranges from 0 to $400{ }^{\circ} \mathrm{C}$. These stages involved mass losses of $100.0 \%$ (found $100.51 \%$ ) for the first and second steps of decomposition, respectively. These mass losses may be due to the successive losses of $\mathrm{C}_{14} \mathrm{H}_{11} \mathrm{Cl}_{2} \mathrm{~N}$ molecule as gases at the given temperature range [41].

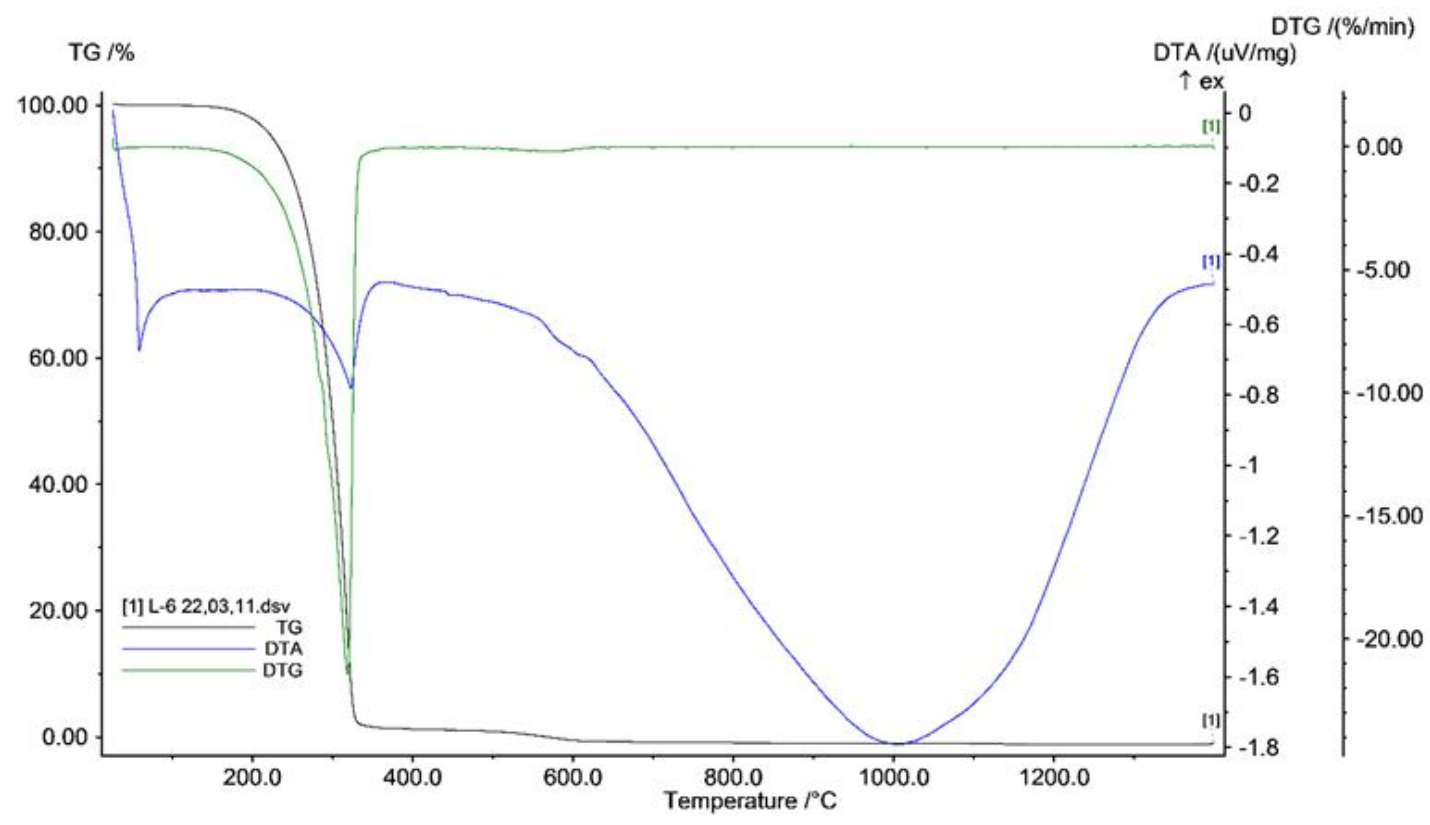

Figure 12 TGA/DTA/DTG curve of ligand L6 
Aytekin et al. / Anadolu Univ. J. of Sci. and Technology - A - Appl. Sci. and Eng. 17 (2) - 2016

\section{CONCLUSIONS}

The Schiff-base compound L6 was synthesized and the structure of L6 was confirmed by spectroscopic (FT-IR, Raman, ${ }^{1} \mathrm{H}$ NMR, ${ }^{13} \mathrm{C}$ NMR, UV-VIS, single crystal X-ray diffraction) and thermal techniques. The vibrational wavenumbers were examined theoretically using quantum chemical computations and the normal modes were assigned by potential energy distribution calculation. The HOMO and LUMO analysis was used to determine the charge transfer within the molecule. The ${ }^{1} \mathrm{H}$ and ${ }^{13} \mathrm{C}$ NMR chemical shifts of $\mathbf{L 6}$ compound was analyzed. The geometrical parameters of the title compound are in good agreement with single crystal X-ray results. Crystallographic data for the title compound have been deposited with the Cambridge Crystallographic Data Centre, CCDC reference number 848120 The characteristic double bond $\mathrm{C}=\mathrm{O}$ shows vibrational absorption around $1700 \mathrm{~cm}^{-1}$, but there was no identification for the free carbonyl group in the title compound. On the basis of this, one can conclude that this compound is mainly existed in Schiff base form, in agreement with the conclusion which was obtained from NMR and Raman studies. Detailed vibrational assignments of the compound was ascribed to its structural vibrations. The assignments of fundamental frequencies were confirmed by the agreement between the calculated and experimental results. Comparison of the calculated vibrational spectra with the experimental data provides reliable assignments of all observed bands in FT-IR and Raman spectra of the title compound. The reasonable agreement between the theoretical and experimental data reflects to the great extent the suitability of the applied basis set, $6-311++\mathrm{g}(\mathrm{d}, \mathrm{p})$ for this type of work and confirms the suggested structure.

\section{ACKNOWLEDGMENTS}

We would like to thank the BAP of the Anadolu University (Nos. 1102F027 and 1304F064) for its financial support for Gaussian 09 and Gauss View 5.0 programs. The authors are grateful to Mustafa Çobanc1, the SAM, for thermal analysis.

\section{REFERENCES}

[1] Blagus A, Cinčić D, Frisčić T, Kaitner B, Stilinović V. Schiff bases derived from hydroxyaryl aldehydes: molecular and crystal structure, tautomerism, quinoid effect, coordination compounds. Maced J Chem and Chem Eng 2010: 29(2); 117-138.

[2] Dueke-Eze CU, Fasina TM, Idika N. Synthesis, electronic spectra and inhibitory study of some Salicylaldehyde Schiff bases of 2-aminopyridine. AJPAC 2011: 5(2); 13-18.

[3] Khaloji AD, Mighani H, Gotoh K, Ishida H. Synthesis, Characterization, Structure, Ab Initio and DFT Calculations of 2-Amino-N-(3-phenylprop-2-enylidene)aniline. J Chem Crystallogr 2011: 41; $1154-1157$.

[4] Pramanik HAR, Das D, Paul PC, Mondal P, Bhattacharjee CR. Newer mixed ligand Schiff base complexes from aquo-N-(2'-hydroxy acetophenone) glycinatocopper(II) as synthon: DFT, antimicrobial activity and molecular docking study. Journal of Molecular Structure 2014: 1059; 309319.

[5] Singh AK, Pandey SK, Pandey OP, Sengupta SK. Synthesis and spectral characterization of Zn(II) microsphere series for antimicrobial application. Journal of Molecular Structure 2014: 1074; 376-383.

[6] Li ZZ, Gu Z, Yin K, Zhang R, Deng Q, Xiang JN. Synthesis of substituted-phenyl-1,2,4-triazol-3thione analogues with modified d-glucopyranosyl residues and their antiproliferative activities. Eur. J. Med. Chem. 2009: 44; 4716-4720. 
Aytekin et al. / Anadolu Univ. J. of Sci. and Technology - A - Appl. Sci. and Eng. 17 (2) - 2016

[7] Li YG, Dong XW, Ai R, Xu XL, Zhu HL. Synthesis and Crystal Structure of a New Schiff Base Ligand and Its Cobalt(II) Complex ${ }^{1}$. Russian J Coord Chem 2011: 37; 523-527.

[8] Khalaji AD, Chermahini AN, Fejfarova K, Dusek M. Synthesis, characterization, crystal structure, and theoretical studies on Schiff-base compound 6-[(5-Bromopyridin-2-yl)iminomethyl]phenol. Struc Chem 2010: 21; 153-157.

[9] Magar BK, Kirdant AS, Chondhekar TK. Formation of N-salicylidene-p-methylaniline: A kinetic study. Der Chemica Sinica 2014: 5(1); 95-100.

[10] Jadhav SM, Shelke VA, Munde AS, Shankarwar SG, Chondhekar TK. Synthesis, characterization, potentiometry, and antimicrobial studies of transition metal complexes of a tridentate ligand. J Coord Chem 2010: 63(23); 4153-4164.

[11] Shelke VA, Jadhav SM, Shankarwar SG, Munde AS, Chondhekar TK. Synthesis and Characterization of Tetradentate $\mathrm{N}_{2} \mathrm{O}_{2}$ Schiff Base Ligand and its Rare Earth Metal Complexes. J Korean Chem Soc 2011: 55(3); 436-443.

[12] Patel PR, Zele S. Preparation and characterization of some lanthanide complexes involving a heterocyclic $\beta$-diketone. Ind. Chem 1999: 38A; 563-567.

[13] ChemBioDraw Ultra 14 Individual ASL SN Win., Download Individual Two Year Term English Windows, 2014.

[14] Gaussian 09, Revision B.01. Frisch, M. J.; Trucks, G. W.; Schlegel, H. B.; Scuseria, G. E.; Robb, M. A.; Cheeseman, J. R.; Scalmani, G.; Barone, V.; Mennucci, B.; Petersson, G. A.; Nakatsuji, H.; Caricato, M.; Li, X.; Hratchian, H. P.; Izmaylov, A. F.; Bloino, J.; Zheng, G.; Sonnenberg, J. L.; Hada, M.; Ehara, M.; Toyota, K.; Fukuda, R.; Hasegawa, J.; Ishida, M.; Nakajima, T.; Honda, Y.; Kitao, O.; Nakai, H.; Vreven, T.; Montgomery, J. A., Jr.; Peralta, J. E.; Ogliaro, F.; Bearpark, M.; Heyd, J. J.; Brothers, E.; Kudin, K. N.; Staroverov, V. N.; Kobayashi, R.; Normand, J.; Raghavachari, K.; Rendell, A.; Burant, J. C.; Iyengar, S. S.; Tomasi, J.; Cossi, M.; Rega, N.; Millam, J. M.; Klene, M.; Knox, J. E.; Cross, J. B.; Bakken, V.; Adamo, C.; Jaramillo, J.; Gomperts, R.; Stratmann, R. E.; Yazyev, O.; Austin, A. J.; Cammi, R.; Pomelli, C.; Ochterski, J. W.; Martin, R. L.; Morokuma, K.; Zakrzewski, V. G.; Voth, G. A.; Salvador, P.; Dannenberg, J. J.; Dapprich, S.; Daniels, A. D.; Farkas, Ö.; Foresman, J. B.; Ortiz, J. V.; Cioslowski, J.; Fox, D. J. Gaussian, Inc., Wallingford CT, 2009.

[15] Dennington RD, Keith TA, Millam JM, GaussView 5.0.8, Gaussian Inc., Wallingford CT 2008.

[16] Becke AD. Density-functional thermochemistry. III. The role of exact Exchange, J Chem Phys 1993: 98; 5648-5652.

[17] Lee C, Yang W, Parr RG. Development of the Colle-Salvetti correlation-energy formula into a functional of the electron density, Phys. Rev. B 1988: 37; 785-789.

[18] Jamróz, M.H. Vibrational Energy Distribution Analysis: VEDA 4 Program, Warsaw, 2004.

[19] Sundaraganesan N, Ilakiamani S, Salem H, Wojciechowski PM, Michalska D. FT-Raman and FT-IR spectra, vibrational assignments and density functional studies of 5-bromo-2-nitropyridine. Spectrochim. Acta A 2005: 61; 2995-3001. 
Aytekin et al. / Anadolu Univ. J. of Sci. and Technology - A - Appl. Sci. and Eng. 17 (2) - 2016

[20] Sundaraganesan N, Ilakiamani S, Subramani P, Dominic Joshua B. Comparison of experimental and ab initio HF and DFT vibrational spectra of benzimidazole. Spectrochimica Acta Part A 2007: 67; 628-635.

[21] Jamróz MH. Vibrational energy distribution analysis (VEDA): Scopes and limitations. Spectrochimica Acta Part A 2013: 114; 220-230.

[22] Bürgi HB, Dunitz JD. Molecular conformation of benzylideneanilines; relation to electronic structure and spectra. J. Chem. Soc. D, 1969: 472-473.

[23] Bernstein J. Conformational Studies. Part 111.1 Crystal and Molecular Structures of N- (2,4-D ichlorobenzylidene)aniline. J Chem Soc Perkin Trans 1972: 2; 946-950.

[24] Vergoten G, Fleury G. Vibrational Spectroscopy Of Liquid Crystals 2. Normal Coordinate Analysis Of Benzaniline: Basis Structure For Some Liquid Crystals, Journal of Molecular Structure 1976: 30(2); 347-359.

[25] Bernstein J, Schmidt GMJ. Conformational Studies. Part 1V.1 Crystal and Molecular Structure of the Metastable Form of N-(p-Chlorobenzvlidene)-p-chloroaniline, a Planar Anil, J Chem Soc Perkin Trans 1972: 2; 951-955.

[26] Udhayakala P, Jayanthi A, Rajendiran TV, Gunasekaran S. Computation and interpretation of vibrational spectra, thermodynamical and HOMO-LUMO analysis of 2-chloro-4-nitroaniline. Int $\mathbf{J}$ ChemTech Res 2011: 3(4); 1851-1862.

[27] Prasad JV, Rai SB, Thakur SN. Overtone spectroscopy of benzene derivatives using thermal lensing. Chemical Physics Letters 1989: 164(6); 629-634.

[28] Hayd H, Savin H, Stoll A, Preuss H, Becker G. Influence of substituents on bond lengths. Journal of Molecular Structure (Theochem) 1988: 165; 87-97.

[29] Gough KM, Henry BR. CH Stretching Overtone Spectra of Nltrobenzene and Its Deuterated Derivatives. Assignment of the Ortho CH. J Phys Chem 1989: 87; 3804-3805.

[30] Mizugai Y, Katayama M, Nakagawa N. Substituent Effect on the Fifth Overtones of the Aryl C-H Stretching Vibrations in Disubstituted Benzenes. J Am Chem Soc 1981: 103; 5061-5063.

[31] Traetteberg M, Hilmo I, Abraham RJ, Ljunggren S. The Molecular Structure Of N-BenzylideneAnılıne. Journal of Molecular Structure 1978: 48; 395-405.

[32]Rukiah M, Lefebvre J, Descamps M, Hemon S, Dzyabchenko A. Ab initio structure determination of m-toluidine by powder X-ray diffraction. J Appl Cryst 2004: 37; 464-471.

[33] Stuart B. Infrared Spectroscopy: Fundamentals and Applications. 2004: John Wiley \& Sons, Inc. ISBNs: 0-470-85427-8 (HB); 0-470-85428-6 (PB).

[34] Varsanyi G. Assignments of Vibrational Spectra of Seven Hundred Benzene Derivatives. Adam Hilger Ed. 1974: Vol. 1-2.

[35] Silverstein M, Clayton Basseler G, Morill C. Spectrometric Identification of Organic Compounds. 2001: Wiley New York. 
Aytekin et al. / Anadolu Univ. J. of Sci. and Technology - A - Appl. Sci. and Eng. 17 (2) - 2016

[36] Kozhevina LI, Prokopenko EB, Rybachenko VI, Titov EV. Investıgation Of Azomethine Group Vibrations In Aromatic Schiff Bases And Their N-Oxides By Vibrational Spectroscopy Methods. Journal of Structural Chemistry 1995: 36; 276-280.

[37] Suydam FH. The C-N Stretching Frequency in Azomethines. Analytical Chemistry, 1963: 35(2); 193-195.

[38] Meić Z, Baranović G. Vibrational Spectra of trans-N-Benzylideneaniline and Its Isotopomers. Pure \&Appl. Chem 1989: 61(12); 2129-2138.

[39] Campagnaro GE, Wood JL. The vibrational spectra and origin of torsional barriers in some aromatic systems. Journal of Molecular Structure 1970: 6; 117-132.

[40] Figueroa AK, Peña CR, Campos-Vallette MM. Valence Force Constants of NBenzylideneanilines. Z Naturforsch 1989: 44b; 923-927.

[41] Tyagi P, Chandra S, Saraswat BS, Sharma D. Design, spectral characterization, DFT and biological studies of transition metal complexes of Schiff base derived from 2-aminobenzamide, pyrrole and furan aldehyde. Spectrochimica Acta Part A: Molecular and Biomolecular Spectroscopy 2015: 143; 1-11.

[42] APEX2 and Saint, Bruker AXS 2007: Madison, Wisconsin, USA.

[43] Sheldrick GM. SHELXS-97, Phase annealing in SHELX-90: direct methods for larger structures. Acta Crystallogr 1990: 46; 467-473.

[44] Spek AL. Platon-A Multipurpose Crystallographic Tool Utrecht; Utrecht University 2005: The Netherlands.

[45] Macrae CF, Edgington PR, McCabe P, Pidcock E, Shields GP, Taylor R, Owler M Van de Streek. Mercury: visualization and analysis of crystal structures. J Appl Crystallogr 2006: 39; 453-457. 